\title{
Estimation of in situ distribution of carbonate produced from cold-water octocorals on a Japanese seamount in the NW Pacific
}

\author{
Asako K. Matsumoto ${ }^{1,2, *}$ \\ ${ }^{1}$ Planetary Exploration Research Centre (PERC), Chiba Institute of Technology (Chitech), 2-17-1, Tsudanuma, Narashino, \\ Chiba 275-0016, Japan \\ ${ }^{2}$ Centre for the Comparative Study of Civilizations and Cultures, Reitaku University, 2-1-1, Hikarigaoka, Kashiwa-shi, \\ Chiba-ken 277-8686, Japan
}

\begin{abstract}
The importance of the deep, cold-water hexacorals as cold-water bioherms and their contribution to marine carbonate production has been demonstrated elsewhere. However, no research has been carried out to examine the contribution of carbonate production by deep, coldwater octocorals (CWOC), even though this group comprises a major component of cold-water coral fauna in the NW Pacific. To assess the contribution of CWOC carbonate production on the Shiribeshi Seamount $\left(43^{\circ} 34-36^{\prime} \mathrm{N}, 139^{\circ} 31-35^{\prime} \mathrm{E}\right)$, Sea of Japan, remotely operated vehicle (ROV) dive video archives and deposited specimens of Primnoa pacifica (Octocorallia, Primnoidae) were analysed. To estimate the carbonate weight per colony, the diameter of cross-sections of branches or stems and the carbonate weight per volume of specimens were measured. Colony volumes were then calculated from the video footage. The amount of carbonate standing stock (CSS) was calculated at each dive line by analysing the distribution of CWOC and specimen data. The average $( \pm$ SD) weight percentage of sclerites per colony of $P$. pacifica was $37.93 \pm 7.45 \%$, with the range 25.47 to $49.19 \%$. It was estimated that the total amount of CSS of coral would be over $0.65 \mathrm{t}$ at all dive lines $\left(22753 \mathrm{~m}^{2}\right)$ at the seamount. Maximum CSS was $70.64 \mathrm{~g} \mathrm{~m}^{-2}$ and maximum carbonate production was up to $3.61 \pm$ $0.06 \mathrm{~g} \mathrm{~m}^{-2} \mathrm{yr}^{-1}$. In comparison with the other CSS in non-tropical areas, our results show that CWOC may potentially contribute to carbonate production in cold-water environments.
\end{abstract}

KEY WORDS: Carbonate production - Sea of Japan · Deep-water gorgonian corals · Non-tropical · Deep sea $\cdot$ Deep-sea coral

\section{INTRODUCTION}

Deep, cold-water corals (CWCs) are composed of more than one taxonomic group. The 2 major groups of CWCs are scleractinian corals and gorgonian corals. Scleractinian (Anthozoa, Hexacorallia) corals construct skeletons of aragonite, while gorgonian corals (Anthozoa, Octocorallia) construct skeletons made primarily from both an organic gorgonin fraction and an Mg-calcite fraction. The distribution of cold-water hexacorals, such as Lophelia pertusa coral which grows on North Sea oil rigs (Bell \& Smith 1999) or L. pertusa carbonate mounds in the North Sea or Scandinavian shelf (Wilson 1988, Frei- wald \& Roberts 2005), and other details on their carbonate contribution as bioherms, especially in the eastern Atlantic, have already been well described. In contrast, the major species of deep CWCs in Pacific Ocean waters are gorgonian octocorals, and their contribution to marine carbonate production is still unknown (Malakoff 2003, Etnoyer \& Morgan 2005, Matsumoto 2005).

\section{Non-tropical carbonate production}

With respect to their geological and palaeontological importance, deep, cold-water hexacorals are viewed as 
constructors of bioherms. Since Linnaean times, the existence of CWCs has been known, and these scleractinian corals have been identified as the main framework constructor in the northeast Atlantic (Freiwald 1998).

Carbonate sedimentary processes occur regardless of temperature or latitude (Nelson 1988, my Fig. 1). The vast size of deep-water habitats and the abundance of CWCs in many locations emphasizes that the cold-water carbonate system may be of global significance (Freiwald et al. 2002). Wilson reported on a CWC reef formed by ahermatypic hexacoral Lophelia pertusa in the northern Atlantic (Wilson 1988). Since then, the reef-building capacity of scleractinian corals (especially of $L$. pertusa) has become a focus of attention in contrast to tropical, shallow-water coral reefs. There have been no studies of carbonate production by octocoral in cold, deep waters.

\section{Carbonate of octocorals}

Gorgonian corals belong to the subclass Octocorallia, which produces calcium carbonate. Their supporting structures are composed of horny or calcium carbonate skeletons (axis and holdfast) inside the body and magnesium calcite mesoskeletons (sclerites) which are distributed over the surface of the polyp and body and stiffen them. Octocorals can be fossilised as separated sclerites and the calcareous base and axis (Bayer 1955, Lindström 1978, Giammona \& Stanton 1980, Bengtson 1981, Kocurko 1988). It should be noted that these sclerites, holdfasts and axes exist within the same colony at the same time. Grasshoff \& Zibrowius (1983) insisted that fossilised structures such as sclerites or calcareous bases have not been recognized as gorgonian corals and are grouped either as a misidentified taxon or as 'enigmatica'.

Sclerites are the most important taxonomical distinctive morphology for the identification of octocoral species, but it is very difficult to collect disarticulated sclerites dispersed in sediment or limestone. The small size of most sclerites makes them hard to find and collect (Kocurko 1988). In addition, it is very difficult to identify them by micropalaeontological preparation. Bayer (1956) mentioned the near impossibility of identifying isolated sclerite remains and suggested that many investigators have ignored them even when they are observed in samples. Despite the fact that sclerites are common fossils, the study of fossilised sclerites has been neglected because of the difficulty in identifying and collecting them and because there are too few octocoral taxonomists who specialize in fossil taxa (Kocurko 1988, Kocurko \& Kocurko 1992).

In the 5 families of octocorals (Ellisellidae, Ifalukellidae, Chrysogorgiidae, Primnoidae, Isididae), the colony holdfast consists of calcium carbonate (Grasshoff \&

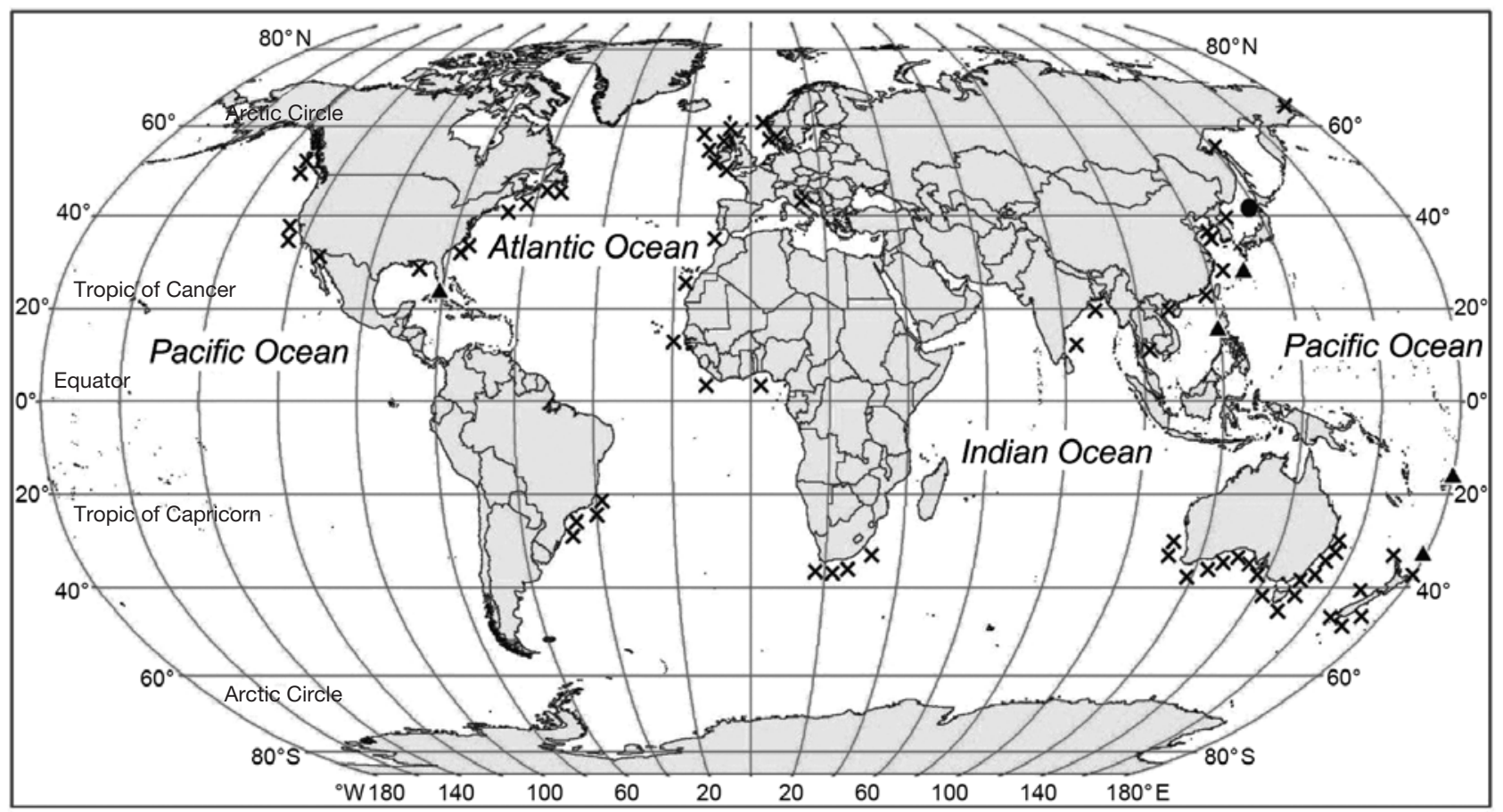

Fig. 1. Distribution of octocoral carbonate deposits in shallow water $(\mathbf{\Lambda})$, modern marine cool-water shelf carbonate sediments in shallow water (X) in Fig. 3 of Nelson (1988) and probability of octocoral carbonate deposits in cold deep waters (•) (present study). Sources of shallow-water octocoral deposit information are Brook (1998), Cary (1918, 1931), and Konishi (1981) 
Zibrowius 1983, Ehrlich et al. 2006). In these families, the existence of preserved axial structures has been reported (Hickson 1938, Bayer 1956, Giammona \& Stanton 1980). Other holdfasts are non-calcified and composed of the horn-like protein gorgonin. Calcified holdfasts contribute to the supply of calcium carbonate to the substrate, and non-calcified holdfasts also bind bottom material (Kocurko 1987). Both calcified holdfasts and crusts on the axes of octocorals have been recorded as fossils (Grasshoff \& Zibrowius 1983, Kocurko \& Kocurko 1992).

\section{Evidence for the contribution of lime by octocorals in shallow water}

There is agreement that Alcyonarians (Anthozoa; Octocorallia) contribute to limestone in shallow tropical waters (Cary 1931, Bayer 1956, Milliman 1974, Konishi 1981). Moreover, the carbonate cements of alcyonarian spiculite or spicularite have already been identified (Konishi 1981, Brook 1998).

Gorgonians (Anthozoa; Octocorallia) also have a tendency to envelop and encrust sediment with the basal holdfast of the colony and are responsible for extensive submarine lithification (Kocurko 1987). Cary (1918) indicated that gorgonian coral sclerites are durable and are incorporated into the reef limestone because they are observed in nearly all bottom samples from reefs and soft mud in the Caribbean. It has been noted that $1 \mathrm{t}$ of limestone per acre $\left(=4046.86 \mathrm{~m}^{2}\right)$ can be released annually by gorgonians in the form of sclerites (Bayer 1961). Fig. 1 shows known alcyonarian spiculite occurrence and octocoral sedimentation in shallow tropical water. However, deep, cold-water octocoral (CWOC) limestone has not been found because no one has ever considered the possibility that octocorals have made a contribution to sedimentation in deep and cold waters.

\section{Objectives of the present study}

To determine the carbonate production of octocorals as a potential constructor of biological-origin carbonate, such as bioherms, biostrome, and limestone and carbonate sediment, the carbonate standing stock (CSS) and carbonate production of CWOC on the Shiribeshi Seamount in the NW Pacific were calculated by analysing video recordings from submersibles and by examination of specimens. The main objectives of this study were to estimate the potential carbonate contribution of CWOC as well as to provide basic scientific information on gorgonian corals (Anthozoa; Octocorallia) in cold and deep environments.

\section{MATERIALS AND METHODS}

Study site. The Shiribeshi Seamount $\left(43^{\circ} 34-36^{\prime}\right.$ N, $\left.139^{\circ} 31-35^{\prime} \mathrm{E}\right)$ is an extinct, cone-shaped mid-Pleistocene arc volcano located in the northern Okushiri Ridge, the northernmost section of the Sea of Japan in the NW Pacific (Fig. 2a). The northern Okushiri Ridge is located in the convergent tectonic belt along the eastern margin of the Sea of Japan and on the westward down-step of the Suttsu tectonic line. The Suttsu tectonic line is the convergent tectonic boundary between the northeast Japan Arc and the JapanChishima (Kuril) Arc. Several earthquakes (surfacewave magnitude, $M_{\mathrm{s}}>7$, Richter scale) are known to have occurred in the area (Takeuchi \& Tanaka 1990). The relative height of the seamount is approximately $3000 \mathrm{~m}$ on the western side and $1600 \mathrm{~m}$ on the eastern side, and its diameter is ca. $10 \mathrm{~km}$ at a depth of $1800 \mathrm{~m}$ (Ogawa et al. 2002). The shallowest depths at the summit of the seamount are about 120 to $200 \mathrm{~m}$, and there is a buried volcanic crater which has a major fault zone extending north-northwest to south-southeast. The volcanic cone of the seamount is composed of pillow lavas, sheet flows and hyaloclastites of basalt and andesite (Takeuchi \& Tanaka 1990). It is known that high-abundance CWOC communities are distributed on this seamount and that they have a high degree of biodiversity compared to other areas of the Sea of Japan (Matsumoto 2005).

The northern area of the Sea of Japan is located in the cold-temperate zone. The warm water current, the Tsushima Current, comes from the southern tropical or sub-tropical zone and flows to the Sea of Okhotsk. This current affects Japanese weather on the Sea of Japan side. The fauna in the Sea of Japan is said to be related to the fauna in the Sea of Okhotsk and the Bering Sea (Broch 1935, Matsumoto 2005).

Materials and dives. A total of 8 deep, cold-water Primnoa pacifica specimens which had been collected in and prior to 2001 from the Shiribeshi Seamount within a depth range of 350 to $505 \mathrm{~m}$ and deposited in the National Science Museum Tokyo (NSMT) were used in our study. The water temperature where the gorgonian specimens were collected ranged from 0.56 to $0.65^{\circ} \mathrm{C}$ in the summer of 2001 . The specimens were fixed with formalin and stored in ethanol, either dried or frozen. Subsamples of cross-sections and sclerites were obtained from some of these specimens.

A total of 2055 coral colonies were counted and geological substrate was also observed during the video analysis. The video footage examined was from Dives \#529, \#530, \#531 and \#532 taken by the remotely operated vehicle (ROV) 'Dolphin $3 \mathrm{~K}^{\prime}$ and deposited in the Japan Agency of Science and Technology (JAMSTEC) video archives. 
a

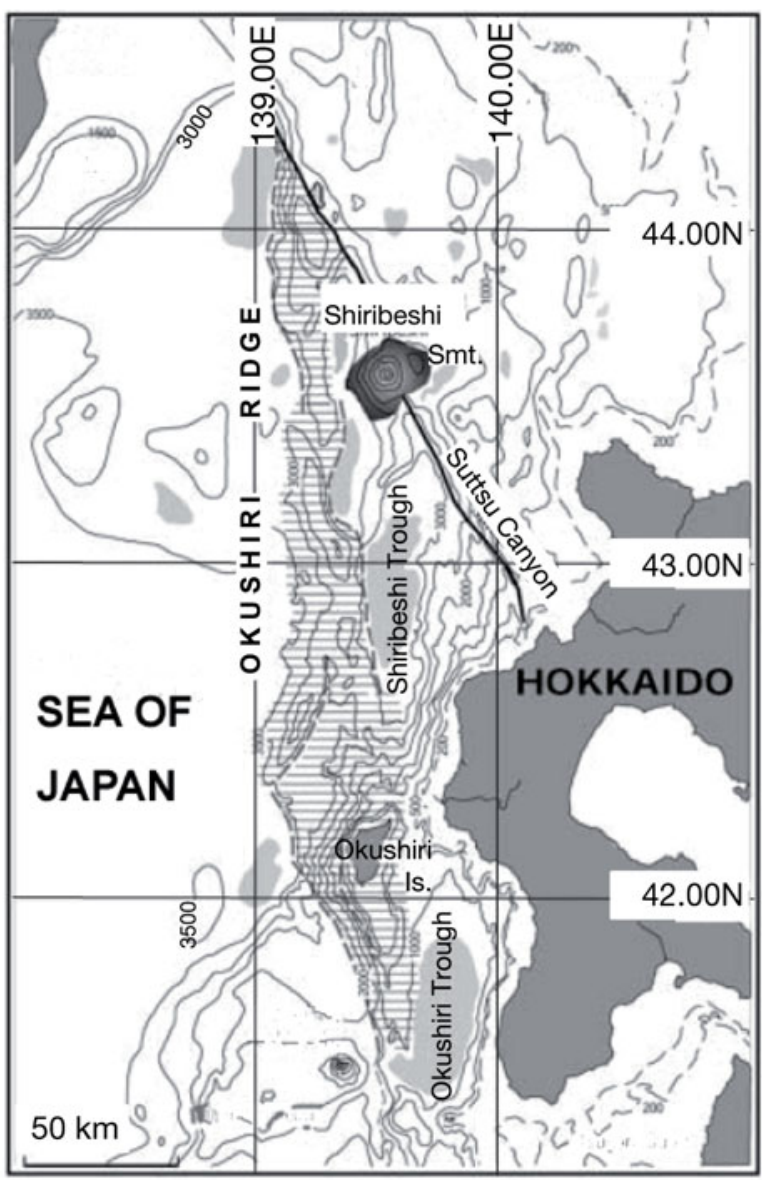

b

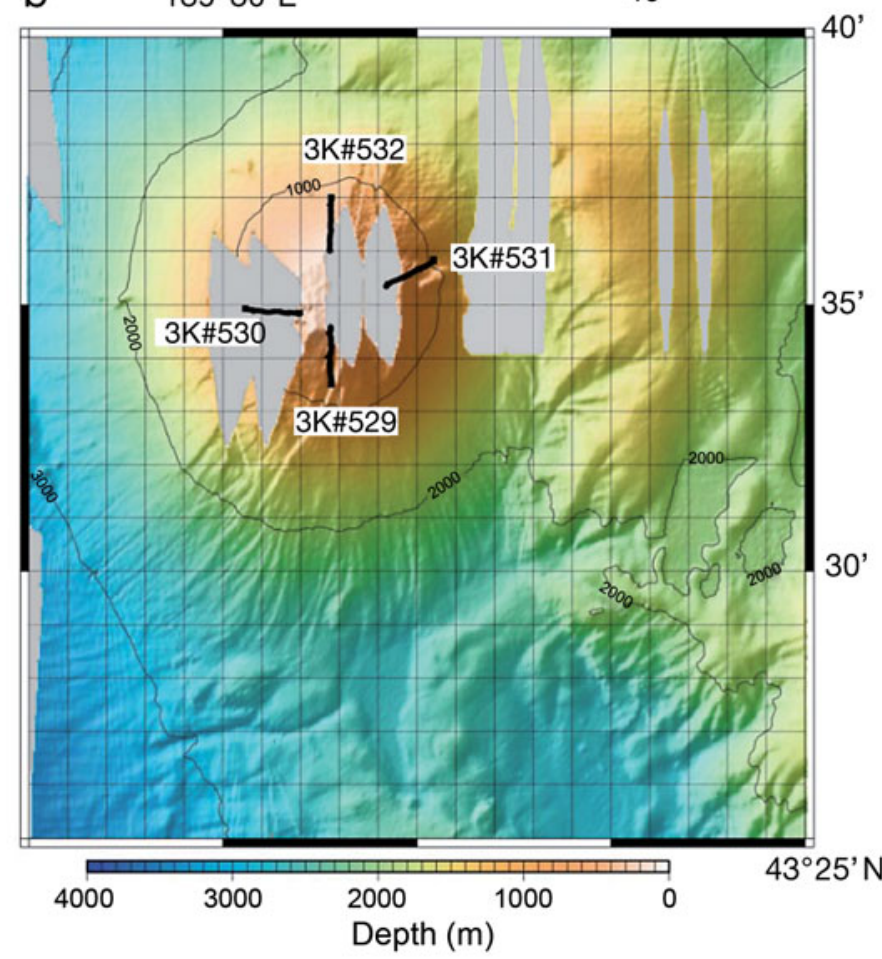

Fig. 2. (a) Location of the Shiribeshi Seamount on the intersection of the northern Okushiri Ridge and the Suttsu tectonic line, modified from Ogawa et al. (2002). (b) Multibeam topography of the Shiribeshi Seamount and the transects of Dives \#529 to \#532. Contour intervals (solid lines) are (a) $500 \mathrm{~m}$ and (b) $1000 \mathrm{~m}$. Gray areas in (b) = no data

Vertical profiles of environmental factors such as water temperature, salinity, and dissolved oxygen (DO) concentration for 'Dolphin 3K' Dives \#529 to \#532 between the depths of 0 and $1037 \mathrm{~m}$ were recorded with a SeaBird SBE19 CTD attached to the vehicle. In order to determine the volume of carbonate produced by CWOC on the Shiribeshi Seamount the following procedures were undertaken.

Estimation of carbonate and inorganic matter weight/volume. The percentage of organic and inorganic matter in the Primnoa pacifica specimens was calculated in dry weight and dry weight per volume $\left(\mathrm{g} \mathrm{cm}^{-3}\right)$, respectively. Because fossil octocorals exist as carbonate crust or limestone, the amount of inorganic matter $\left(\mathrm{MgCO}_{3}\right)$ of octocoral colonies (axis and sclerites) needs to be estimated. A fragment of each specimen with the largest diameter was cut into a piece of about 1 to $2 \mathrm{~cm}$ long by a low-speed saw (ISOMET Buehler), and the length, dry weight, and diameter with polyps were measured (Table 1). Next, the specimens were treated in $5 \%$ bleach (sodium hypochlorite) until all coenenchyme with sclerites were completely disintegrated from the axis, rinsed repeatedly 5 to
6 times with distilled water until no trace of organic debris could be detected in the water, and then stored in ethanol. The coral segments were completely dried on a hot plate at $80^{\circ} \mathrm{C}$, weighed after cooling to room temperature, and then the percentage of the total dry weight of the specimen was calculated. The axial skeleton was isolated from the colony and then the dry weight of the length of the axis was measured. The fossil axes or holdfasts of octocorals are commonly found as whole calcified parts which have the same shape as the axes or holdfasts (Grasshoff \& Zibrowius 1983, Kocurko \& Kocurko 1992). In this study, the word 'carbonate' means sclerites and 'inorganic matter' means sclerites + axial skeletons. The growth rings of the axial skeletons were counted to estimate the age of the branch or stem.

Estimation of the size of colonies recorded in the video footage. Because there were no scales in the archival ROV video recordings and the distance to the objects being filmed and/or the magnification of the camera varied continuously, it was very difficult to directly measure the size or volume of colonies from the videos. Using the deposited specimens of Primnoa 
Table 1. Primnoa pacifica. Organic and inorganic (axis and sclerite) matter as a percentage of dry weight and as dry weight per volume $\left(\mathrm{g} \mathrm{cm}^{-3}\right)$. The length, dry weight, and diameter of branch fragments from each sample were measured. They were then treated in bleach and dried completely before being reweighed. NSMT: National Science Museum Tokyo

\begin{tabular}{|c|c|c|c|c|c|c|c|c|c|c|c|}
\hline Sample no. & $\begin{array}{l}\text { Depth } \\
\text { (m) }\end{array}$ & $\begin{array}{c}\text { Age } \\
\text { (yr) }\end{array}$ & $\begin{array}{l}\text { Axis } \\
(\%)\end{array}$ & $\begin{array}{c}\text { Sclerite } \\
(\%)\end{array}$ & $\begin{array}{c}\text { Organic } \\
(\%)\end{array}$ & $\begin{array}{c}\text { Inorganic } \\
\text { (sclerite + axis) } \\
(\%)\end{array}$ & $\begin{array}{l}\text { Axis/ } \\
\text { volume } \\
\left(\mathrm{g} \mathrm{cm}^{-3}\right)\end{array}$ & $\begin{array}{c}\text { Sclerite/ } \\
\text { volume } \\
\left(\mathrm{g} \mathrm{cm}^{-3}\right)\end{array}$ & $\begin{array}{c}\text { Axis }+ \\
\text { sclerite/volume } \\
\left(\mathrm{g} \mathrm{cm}^{-3}\right)\end{array}$ & $\begin{array}{l}\text { Organic/ } \\
\text { volume } \\
\left(\mathrm{g} \mathrm{cm}^{-3}\right)\end{array}$ & $\begin{array}{l}\text { Dry wt/ } \\
\text { volume } \\
\left(\mathrm{g} \mathrm{cm}^{-3}\right)\end{array}$ \\
\hline NSMT-Co1407 & - & 17.8 & 53.24 & 34.20 & 12.56 & 87.44 & 0.28 & 0.18 & 0.46 & 0.07 & 0.53 \\
\hline NSMT-Co1408 & - & 9 & 37.07 & 39.99 & 22.94 & 77.06 & 0.25 & 0.27 & 0.51 & 0.15 & 0.66 \\
\hline NSMT-Co1409a & - & 28.6 & 51.78 & 36.68 & 11.54 & 88.46 & 0.18 & 0.13 & 0.31 & 0.04 & 0.35 \\
\hline NSMT-Co1412 & 385 & 5.2 & 11.64 & 36.65 & 51.71 & 48.29 & 0.04 & 0.12 & 0.16 & 0.17 & 0.32 \\
\hline NSMT-Co1413 & 350 & 15.2 & 54.45 & 25.47 & 20.08 & 79.92 & 0.20 & 0,09 & 0.29 & 0.07 & 0.36 \\
\hline NSMT-Co1414 & 505 & 13.4 & 38.78 & 43.35 & 17.87 & 82.13 & 0.17 & 0.19 & 0.35 & 0.08 & 0.43 \\
\hline NSMT-Co1415 & 505 & 7.8 & 7.48 & 49.19 & 43.33 & 56.67 & 0.03 & 0.23 & 0.26 & 0.20 & 0.46 \\
\hline
\end{tabular}

pacifica collected at the Shiribeshi Seamount, a scale for the branch diameter range for the Primnoidae colonies was defined. This provided us with a standard scale (basic scale, BS) for Primnoidae colonies, and their size could be calculated/estimated from the video or still photographs (Fig. 3).

First, to estimate the size of coral in situ, the diameter of a cross-section of each previously collected sample branch or stem was measured, and the diameter and area of the cross-section were calculated. Three diameter values (minimum, median and maximum) were used as the BS for the next calculation.

Second, in accordance with Matsumoto (2005), the definition of 3 morpho-types of primnoid corals were used for video identification of deep CWOC as follows: large colonies with more than 100 branches (Fig. 3a), colonies with other shapes, and singlestalk colonies (Fig. 3b). To measure the sizes of the colonies, the branch diameters measured from the specimens in Table 2 were used for the scale parameter. Five large colonies, 8 singlestalk colonies, and 13 colonies of other shapes were randomly selected from the video footage (Table 3).

Height and fan area were measured to estimate the size parameters of the entire colony, and the methodology using height and fan area to estimate the size was one commonly used for the determination of both shallow-water and deep-water gorgonian size (Grigg 1974a, Velimirov 1976, Mistri \& Ceccherelli 1994, Mistri 1995, Weinbauer \&

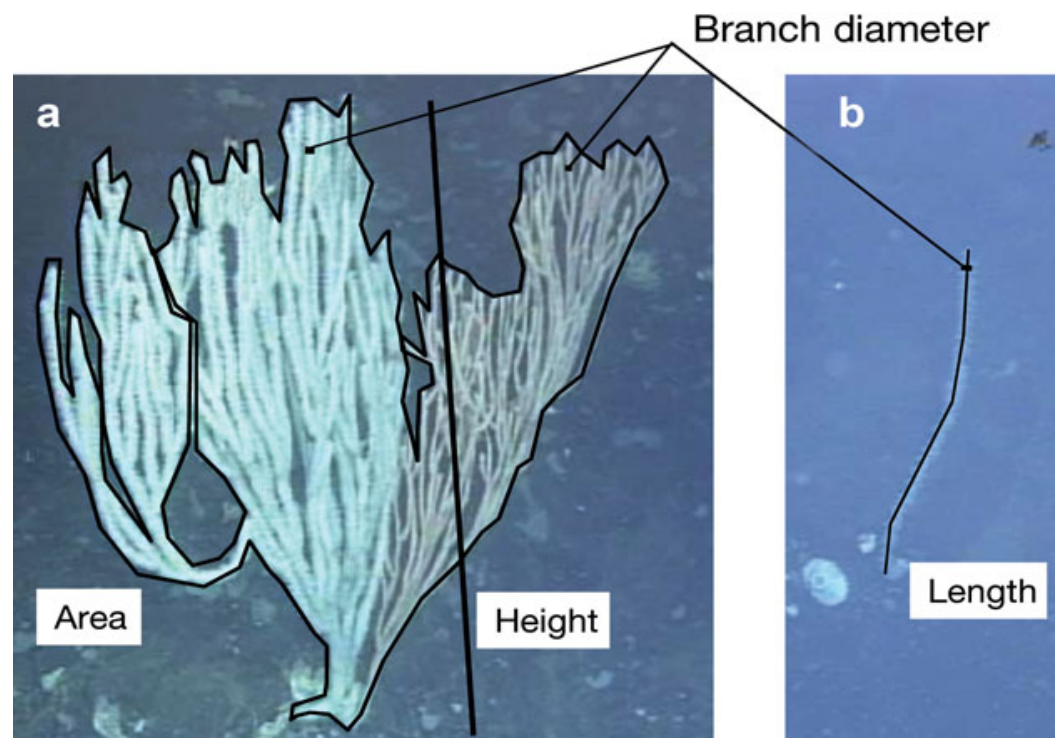

Fig. 3. Primnoa pacifica. (a) Large colony with more than 100 branches; (b) single-stalk colony. Method for estimating size. Scale was defined based on the branch diameters (black rectangles [ $\mathbf{\square}$ in a and b, 0.8-1.6 cm) measured from archive specimens. Data for the basic scale (BS) were minimum: $0.8 \mathrm{~cm}$; median: $1.2 \mathrm{~cm}$; and maximum:1.6 cm (see Table 2). Height (vertical line in a), length (black vertical line in b), and area (outline in a) were determined from still images from video footage. Measurements shown in Table 7

Table 2. Primnoa pacifica. Sample diameter and area of a cross-section of a sample branch or stem. All samples were dried and measured. Area of the crosssection was calculated from the diameter of a branch with polyps. NSMT: National Science Museum Tokyo

\begin{tabular}{|lccccc|}
\hline Sample no. & $\begin{array}{c}\text { Part of } \\
\text { colony }\end{array}$ & $\begin{array}{c}\text { Short } \\
\text { diameter } \\
\text { with polyps } \\
\text { (cm) }\end{array}$ & $\begin{array}{c}\text { Long } \\
\text { diameter } \\
\text { with polyps } \\
\text { (cm) }\end{array}$ & $\begin{array}{c}\text { Min. area } \\
\text { of cross- } \\
\text { section } \\
\left(\mathrm{cm}^{2}\right)\end{array}$ & $\begin{array}{c}\text { Max. area } \\
\text { of cross- } \\
\text { section } \\
\left(\mathrm{cm}^{2}\right)\end{array}$ \\
\hline NSMT-Co1407 & Tip & 1.0 & 1.5 & 0.79 & 1.77 \\
NSMT-Co1408 & Tip & 1.0 & 1.3 & 0.79 & 1.33 \\
NSMT-Co1409a & Tip & 0.9 & 1.2 & 0.64 & 1.13 \\
NSMT-Co1409b & Stem & 0.9 & 1.6 & 0.64 & 2.01 \\
NSMT-Co1410 & Stem & 0.9 & 1.0 & 0.64 & 0.79 \\
NSMT-Co1412 & Tip & 0.8 & 1.1 & 0.50 & 0.95 \\
NSMT-Co1413 & Tip & 1.1 & 1.5 & 0.95 & 1.77 \\
NSMT-Co1414 & Tip & 0.8 & 1.4 & 0.50 & 1.54 \\
NSMT-Co1415 & Tip & 1.0 & 1.2 & 0.79 & 1.13 \\
\hline
\end{tabular}




\begin{tabular}{|c|c|c|c|}
\hline 氙 & 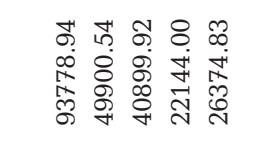 & 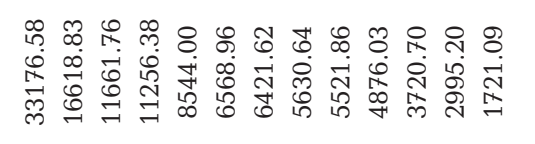 & 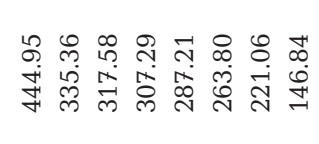 \\
\hline 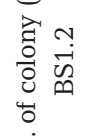 & 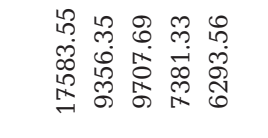 & 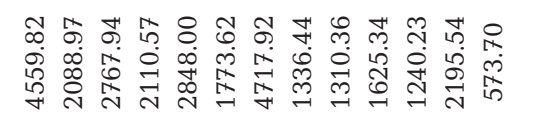 & 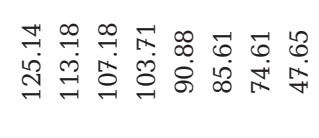 \\
\hline 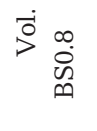 & 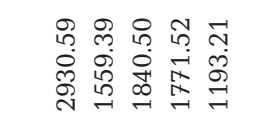 & 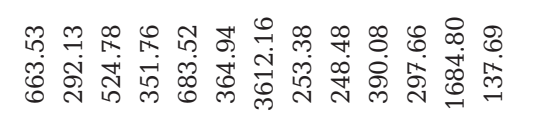 & 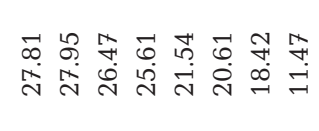 \\
\hline$\widetilde{\sigma}_{\substack{\dot{\infty} \\
\tau}}^{0}$ & 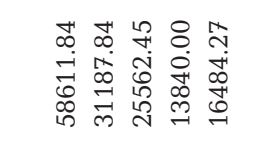 & 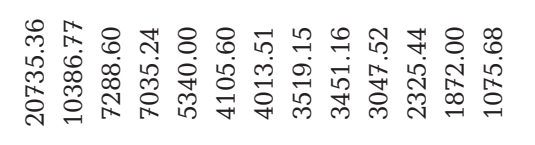 & 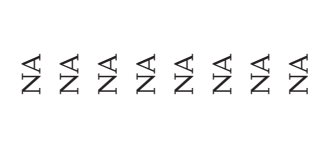 \\
\hline 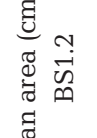 & 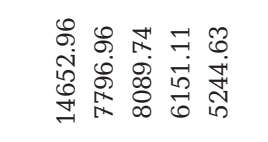 & 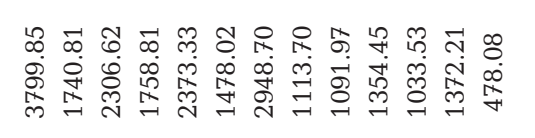 & 艺艺艺艺艺艺艺艺 \\
\hline 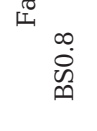 & 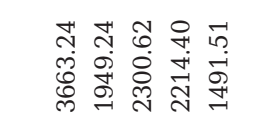 & 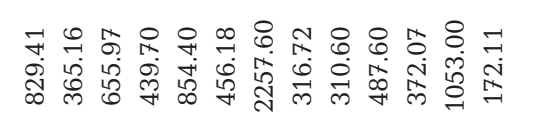 & 艺艺艺艺艺艺艺艺 \\
\hline$\underset{\infty}{\stackrel{0}{\dot{n}^{2}}}$ & 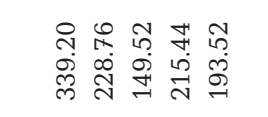 & 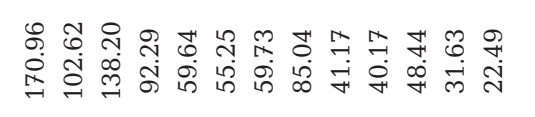 & 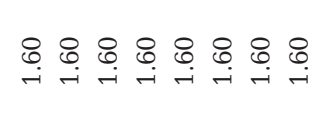 \\
\hline 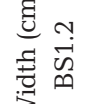 & 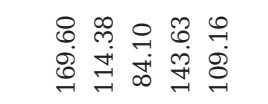 &  & 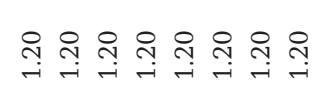 \\
\hline $\begin{array}{l}3 \infty \\
0 \\
0 \\
\infty\end{array}$ & 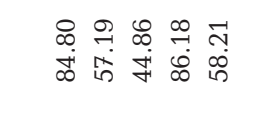 & 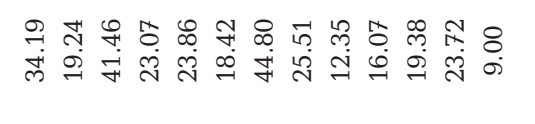 & 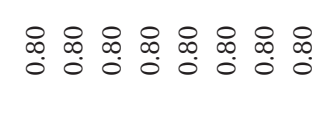 \\
\hline 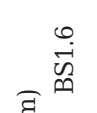 & 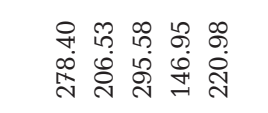 & 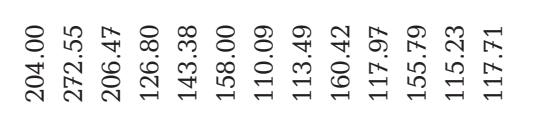 & 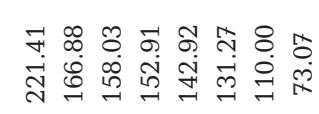 \\
\hline 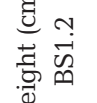 & 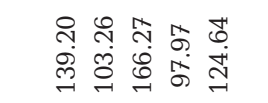 & 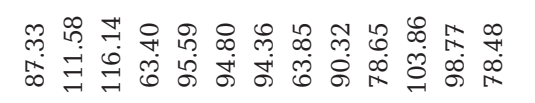 & 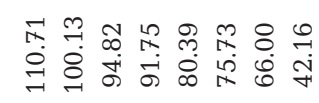 \\
\hline 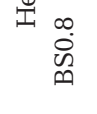 & 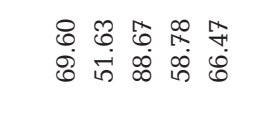 & 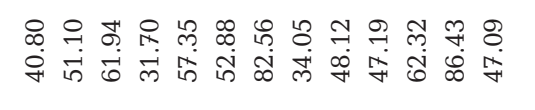 & 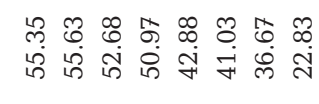 \\
\hline 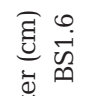 & 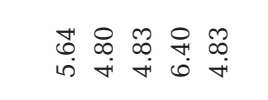 & 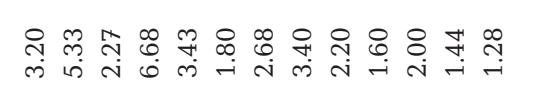 & 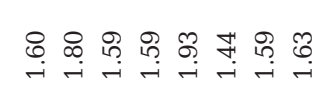 \\
\hline 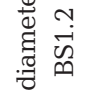 & 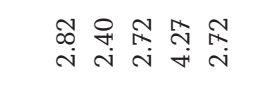 & 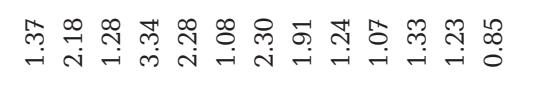 & 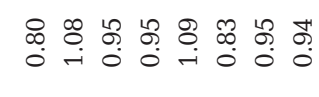 \\
\hline 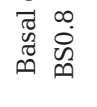 & 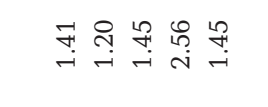 & 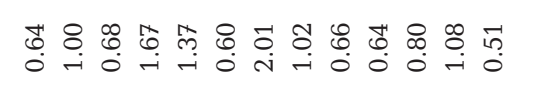 & 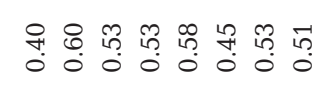 \\
\hline 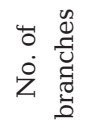 & 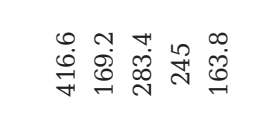 & 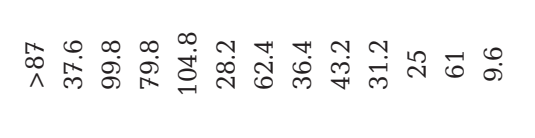 & 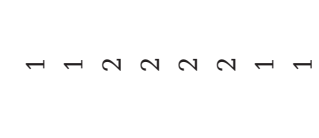 \\
\hline 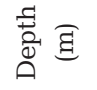 & 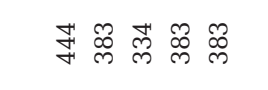 & 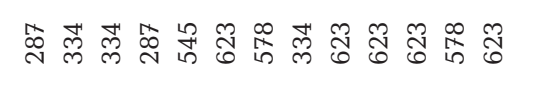 & ఇ్రి స్ర \\
\hline$\stackrel{\nexists}{\dot{\theta}}$ & 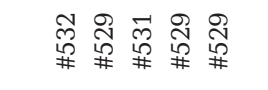 & 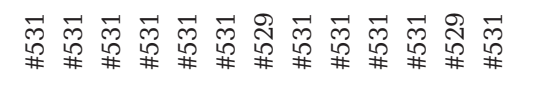 & 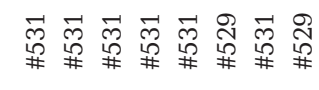 \\
\hline 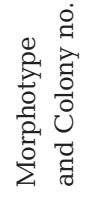 & 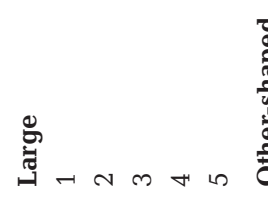 & 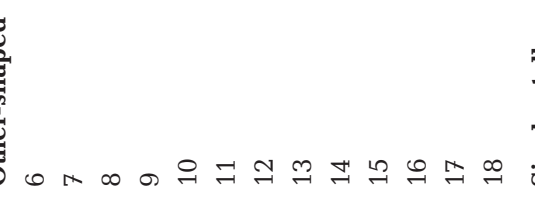 & $\ddot{2}$ \\
\hline
\end{tabular}


Velimirov 1995, Andrews et al. 2002, Lasker et al. 2003, Matsumoto 2004). The number of branch tips in each colony was used for the parameter of fan shape and growth. The genus Primnoa has dichotomous branch shapes. It has already been confirmed that the number of branches is an effective index for a dichotomous branching fan (Matsumoto 2004). Though for pinnate or featherlike colonies the level of branches (primary [mother] branches and secondary branches) is countable and useful for estimating fan size or shape, dichotomous branching corals such as Primnoa spp. have no primary or secondary branches, and therefore this method is not effective for such branching patterns of corals. Therefore, counting the number of branches of colony is currently the better method to estimate the size or fan formation of a colony. The BS (branch diameter) was established on each still image of video footage, and then the length of a single-stalk morphotype colony and the height and area of the large colony or colonies with other shapes were measured (Fig. 3). The volumes $\left(\mathrm{cm}^{3}\right)$ of the singlestalk morphotype colonies were calculated from the length of the colony multiplied by the area of the crosssection $\left(\mathrm{cm}^{2}\right)$, which was calculated from the branch diameter $(\mathrm{cm})$ measured from specimens in Table 2. The volumes $\left(\mathrm{cm}^{3}\right)$ of the large morphotype colonies and colonies with other shapes were calculated from the area of the colony multiplied by the branch diameter (thickness of colony). These calculation data were used to estimate the CSS and carbonate production.

Estimation of carbonate, inorganic matter, and dry weight per colony. The carbonate (sclerites), inorganic matter (sclerites and axis), and dry weights of the colonies (all in g) were estimated for 26 colonies randomly selected from the video footage. These 26 colonies were the same colonies whose size and volume were investigated using 3 BS (Table 3).

The carbonate, inorganic, and dry weights of the colony were estimated using the estimated data for colony volume $\left(\mathrm{cm}^{3}\right)$ in Table 3 multiplied by the calculated data for sclerite per volume $\left(\mathrm{g} \mathrm{cm}^{-3}\right)$, inorganic per volume $\left(\mathrm{g} \mathrm{cm}^{-3}\right)$, and dry weight per volume $\left(\mathrm{g} \mathrm{cm}^{-3}\right)$ in Table 1 . The average value of each morphotype was then calculated.

Estimation of carbonate production. Carbonate (sclerites) and inorganic matter (sclerites + axis) production per year per colony were calculated and then used to determine the linear growth rate. The growth rate data of Primnoa species were calculated using data for Atlantic Canada and the Gulf of Alaska in the Pacific Ocean. The growth rates for Primnoa species in Atlantic Canada have been reported to be a minimum of $3 \mathrm{~mm} \mathrm{yr}^{-1}$, average of $17 \mathrm{~mm} \mathrm{yr}^{-1}$, and maximum of $22 \mathrm{~mm} \mathrm{yr}^{-1}$ (Mortensen \& Buhl-Mortensen 2005). The minimum, average, and maximum growth rates for the species in the Gulf of Alaska are 16, 17.4, and $23.2 \mathrm{~mm}$ $\mathrm{yr}^{-1}$, respectively (Andrews et al. 2002). Therefore, the liner growth rate was almost the same between Primnoa in Atlantic Canada ( $P$. resedaeformis) and in the Gulf of Alaska in the Pacific ( $P$. pacifica), though the species and area are different. The radial growth rates were similar between the Gulf of Alaska (Andrews et al. 2002) and the Sea of Japan (Matsumoto 2007). The linear growth rate shown in a previous study (Andrews et al. 2002, Mortensen \& Buhl-Mortensen 2005) is valid for Primnoa species in both the Atlantic and Pacific and was used for the calculations in the present study. BS branch diameter $(=1.2 \mathrm{~cm})$ from deposited specimens was used in the volume calculations.

Analysis of video footage and the distribution of corals on the seamount. The entire collection of video footage of the dives in the archives was reviewed, and the number of coral individuals counted and the substrate observed. A depth distribution pattern was prepared from the data obtained. A total of 2055 individual corals were identified in all dive lines. To prevent the double-counting of coral colonies, each colony was categorized as one of 3 morphotypes (large, single, other-shaped) in each local distribution pattern in the frame of the video footage, and then the distribution was compared with the subsequent frames. The ROV continued to move forward and climbed up to the top of the seamount in a single direction during the dive. Transects did not move back to the same depth, except at the end of Dive \#529 (Fig. 2b), and that depth did not affect coral distribution. This means that the each dive transect is considered to be a straight line.

The quantitative abundance of coral colonies and other organisms was estimated by dividing the number of colonies by the area calculated from the dive transect data. The 4 dive transects (\#529, \#530, \#531, and \#532) covered about 2056.85, 1892.49, 1726.01, and $1908.92 \mathrm{~m}$, respectively. Thus, a total length of $7584.27 \mathrm{~m}$ in all directions on the seamount was videorecorded. The dive transect lengths were recorded and provided in the dive records. During the dive, several station points were recorded for which the exact time, depth, latitude and longitude were given in the dive records, and it was possible to recognize those points on the video footage. All analyses of the dive video were conducted for each transect segment separated by these stations. The length, depth, and location of each segment were used for our calculations. A previous study found that there was no practical way to estimate the width of the actual video frames because of changing magnification or angles of the video camera lens (Mortensen \& Buhl-Mortensen 2004). In the present study, the width of the video frame was estimated to be between 2 and $4 \mathrm{~m}$ based on estimated colony size (see 'Results: Size estimation'). The ROV kept the same distance from the seafloor during the dive. 
Therefore, the observed area was estimated from the dive transect length multiplied by $3 \mathrm{~m}$, the average of width of the video frame. With this calculation, the 4 dive transect lines covered about 6170.55, 5677.47, 5178.03 , and $5726.76 \mathrm{~m}^{2}$, respectively, and a total area of $22752.81 \mathrm{~m}^{2}$ on the seamount was investigated. The number of colonies per $100 \mathrm{~m}^{2}$ was calculated from the calculation of the area of each segment described above.

To estimate the amount of CSS $\left(g 100 \mathrm{~m}^{-2}\right.$ ) at each depth and of all dive lines of the Shiribeshi Seamount, the data for carbonate weight per volume was calculated from the BS diameter. Finally, carbonate production $\left(\mathrm{g} \mathrm{m}^{-2} \mathrm{yr}^{-1}\right)$ was calculated by multiplying average carbonate production $\left(\mathrm{g} \mathrm{yr}^{-1}\right.$ colony $\left.^{-1}\right)$ in Table 4 by the number of colonies (large, single and other-shaped morphotypes) in each or all dives.

\section{RESULTS}

\section{Colony content}

The results of the determination of the sclerite content of 7 specimens are shown in Table 1. The highest percentage weight of sclerites measured per colony was $49.19 \%$. The percentage of axis weight within a branch slowly increased with age and towards the base as expected, but the percentage weight of sclerites became almost constant after the age of $9 \mathrm{yr}$ (Fig. 4). Branches that had the thinnest axes (age $7.8 \mathrm{yr})$ exhibited the highest percentage of sclerites. Sclerite size is a very important factor for carbonate production in octocorals because Primnoa pacifica has one of the largest polyp sclerites among the gorgonians. The average \pm SD sclerite weight per volume was $0.17 \pm 0.06 \mathrm{~g} \mathrm{~cm}^{-3}$, and the maximum pure sclerite weight per volume was $0.27 \mathrm{~g} \mathrm{~cm}^{-3}$ (Table 1). The average dry weight percentage of sclerites per colony was $37.93 \pm 7.45 \%$ (range 25.47 to $49.19 \%$ ) (Tables $1 \& 5$ ). The volume of axes with polyps $\left(\mathrm{cm}^{3}\right)$ was calculated from the length and diameter of fragments. The percentages or weights of sclerites, axis, and organic matter per volume were estimated.

\section{Size estimation}

Table 2 presents the measured sample diameters of cross-sections of branches or stems with polyps of Primnoa pacifica species. Because the cross-sections were not perfectly circular, the shortest and longest diameters were measured. The diameter range for all specimens was 0.8 to $1.6 \mathrm{~cm}$, and the calculated median diameter was $1.2 \mathrm{~cm}$. These 3 values were used for the measurement of colonies recorded in the dive videos (i.e. for the BS). The BS0.8 data in Table 3 were calculated from the shortest diameter, $0.8 \mathrm{~cm}$ on the BS. The BS1.2 data and BS1.6 data in Table 3 were also calculated from the median diameter $(1.2 \mathrm{~cm})$ and largest diameter $(1.6 \mathrm{~cm})$ for the $\mathrm{BS}$, respectively. The size (height) of primnoid corals on this seamount was estimated to be 42.16 to $166.27 \mathrm{~cm}$ (BS1.2) (Table 3).

\section{Estimation of carbonate, inorganic matter, and dry weight per colony}

The estimated carbonate weights of colonies are given in Table 6. The estimated carbonate weight of the large morphotype colony ranged from 1077.1 to $3009.2 \mathrm{~g}$, and its average value was $1722.4 \mathrm{~g}$ (BS1.2). The estimated carbonate weight of the other-shaped morphotype colony ranged from 98.2 to $807.4 \mathrm{~g}$, and its average value was $383.7 \mathrm{~g}$ (BS1.2). The estimated carbonate weight of the single-stalk morphotype colony ranged from 8.2 to $21.4 \mathrm{~g}$, and its average value was $16.0 \mathrm{~g}$ (BS1.2) (Table 6).

Since I was unable to investigate intact colonies of Primnoa pacifica, the linear growth rate was obtained from Andrews et al. (2002) and Mortensen \& BuhlMortensen (2005). The total linear growth rate per colony per year $\left(\mathrm{yr}^{-1}\right.$ colony $\left.{ }^{-1}\right)$ was determined by multiplying the number of branches per colony (colony ${ }^{-1}$ ) (Table 4 ) by the linear growth rate data of Mortensen \& Buhl-Mortensen (2005) (1*: Atlantic, Canada: minimum growth rate $3 \mathrm{~mm} \mathrm{yr}^{-1}$, average growth rate $17 \mathrm{~mm}$

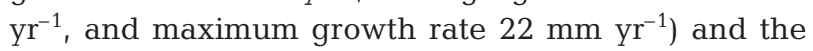
linear growth rate data of Andrews et al. (2002)

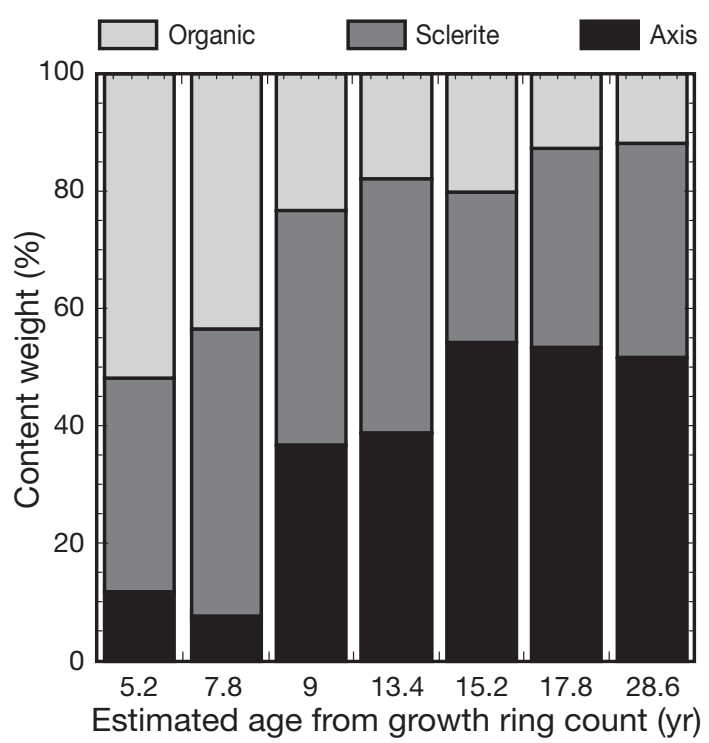

Fig. 4. Primnoa pacifica. Colony content. Weight (\%) of axis, sclerites, and organic matter versus estimated age from growth ring count (yr) 


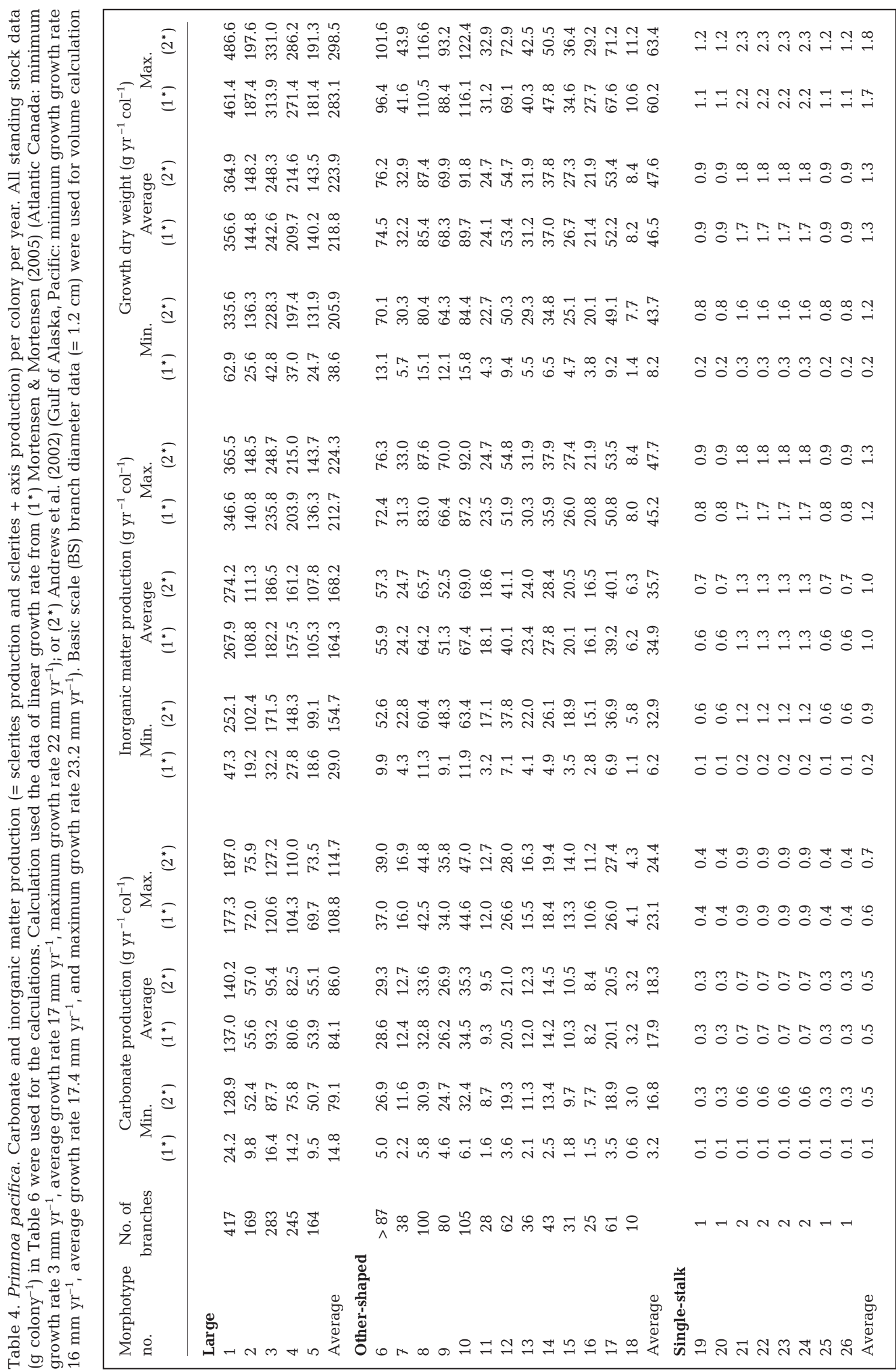


$\left(2^{*}\right.$ : Gulf of Alaska, Pacific: minimum growth rate $16 \mathrm{~mm} \mathrm{yr}^{-1}$, average growth rate $17.4 \mathrm{~mm} \mathrm{yr}^{-1}$, and maximum growth rate $23.2 \mathrm{~mm} \mathrm{yr}^{-1}$ ). Total growth volume per colony per year $\left(\mathrm{mm}^{3} \mathrm{yr}^{-1}\right.$ colony $\left.{ }^{-1}\right)$ was calculated by multiplying the branch cross-section area (with the BS branch diameter $1.2 \mathrm{~cm}$ ) by total linear growth per colony. The total growth branch weight $\left(\mathrm{g}^{-1} \mathrm{yr}^{-1}\right.$ colony $\left.{ }^{-1}\right)$ was calculated by multiplying total growth branch volume $\left(\mathrm{mm}^{-3} \mathrm{yr}^{-1}\right.$ colony $\left.{ }^{-1}\right)$ by the average dry weight per volume, $0.45\left(\mathrm{~g} \mathrm{~cm}^{-3}\right)$ in Table 1 .

Average carbonate production per colony of Primnoa pacifica was $84.1 \mathrm{~g} \mathrm{yr}^{-1}$ colony $^{-1}\left(1^{*}\right)$ and $86.0 \mathrm{~g} \mathrm{yr}^{-1}$ colony $^{-1}\left(2^{*}\right)$ for the large morphotype, $17.9 \mathrm{~g} \mathrm{yr}^{-1}$ colony $^{-1}\left(1^{*}\right)$ and $18.3 \mathrm{~g} \mathrm{yr}^{1}$ colony $^{-1}\left(2^{*}\right)$ for the othershaped morphotype, and $0.5 \mathrm{~g} \mathrm{yr}^{-1}$ colony $^{-1}\left(1^{*}\right)\left(2^{*}\right)$ for the single morphotype (Table 4 ).

\section{Analysis of video footage and distribution of corals on seamount}

The video archive records of 'Dolphin $3 \mathrm{~K}^{\prime}$ ' Dives \#529 to 532 between the depths of 1038 and $142 \mathrm{~m}$ were analysed (Fig. 5). Dive \#531 showed obvious vertical distribution with an extremely high abundance among all dive lines. Vertical profiles of environmental factors such as temperature, salinity and dissolved oxygen concentration are shown in Fig. 6.

The water temperature between the surface layers and $20 \mathrm{~m}$ was stable at ca. $18.34^{\circ} \mathrm{C}$. The profile showed that water temperature quickly decreased, and DO increased, with an increase in depth down to $200 \mathrm{~m}$ and that salinity was stable, which would seem to indicate that the thermocline was shallower than $200 \mathrm{~m}$. (Fig. 6). Water temperature was $<1.0^{\circ} \mathrm{C}$ below $350 \mathrm{~m}$ in all dives in all directions of the seamount. Salinity was stable (from 34.05 to 34.08 PSU) at the seafloor from ca. $150 \mathrm{~m}$ to the bottom during Dive \#531 (Fig. 6).

The DO values were slightly different with depth for each direction of the seamount (Fig. 6). DO was $>5.5 \mathrm{ml} \mathrm{l}^{-1}$ in water shallower than 240 to $377 \mathrm{~m}$ in each dive. The DO at the deepest point of each dive was in all cases $4.6 \mathrm{ml} \mathrm{l}^{-1}$ at a depth range of 779 to $1037 \mathrm{~m}$.

Table 5. Percentage of octocorallia screlite by weight in colony. Note that this is the first study to have examined non-tropical species. Cal.: calcite; MgC.: Mg-calcite; Arag.: aragonite. In cases were the original species name in the reference does not exist, probable scientific names are shown in parentheses

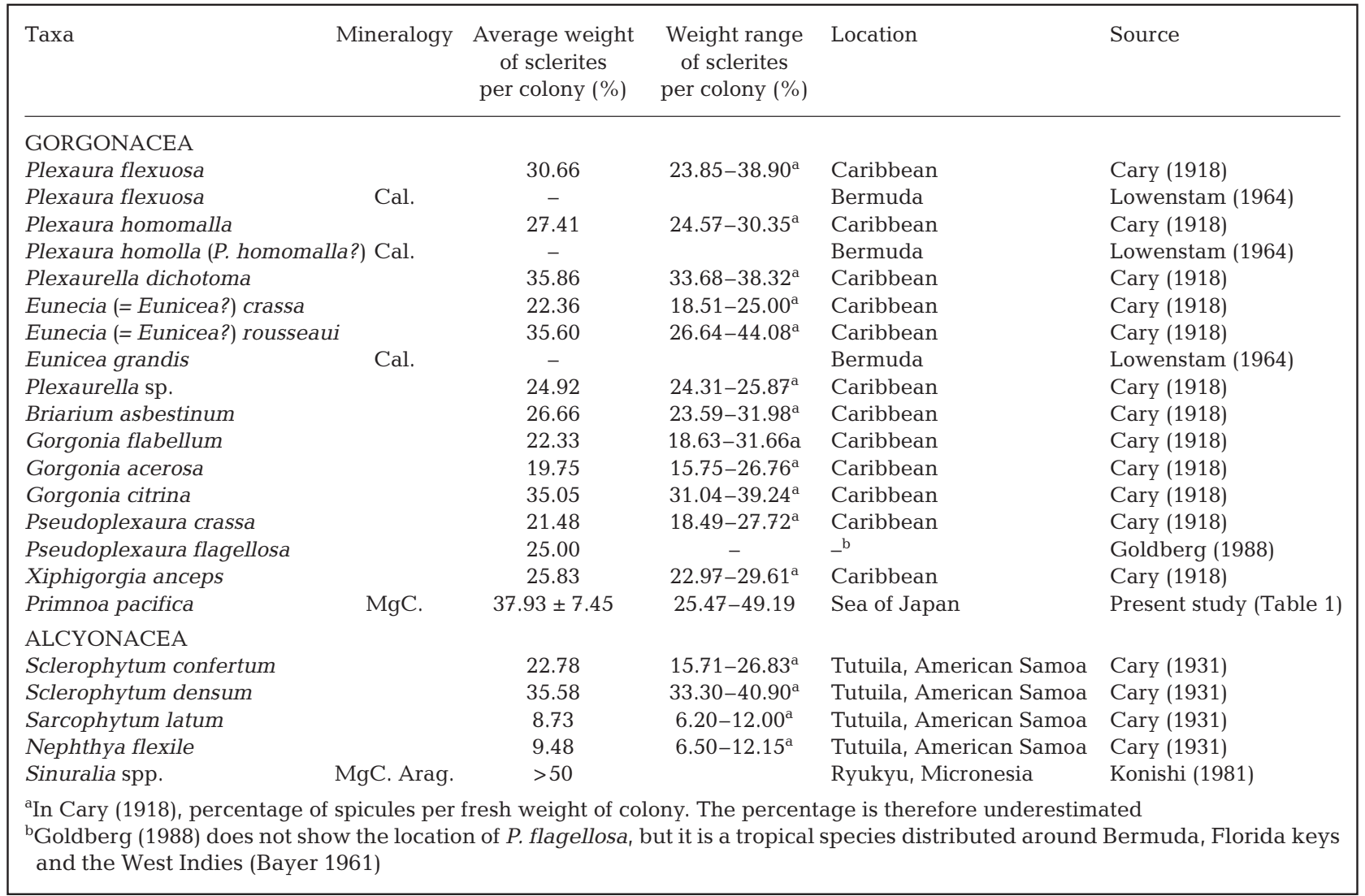


Table 6. Primnoa pacifica. Carbonate weight of colony (= sclerites weight of colony in g), calculated using data in Tables 1 and 3. For the calculation, the mean value of the sclerite weight/volume in Table 1 was used. All data were calculated from the basic scale (BS) diameters $0.8,1.2$, and $1.6 \mathrm{~cm}$, respectively

\begin{tabular}{|c|c|c|c|c|c|c|c|c|c|}
\hline \multirow{2}{*}{$\begin{array}{l}\text { Morphotype } \\
\text { and Colony }\end{array}$} & \multicolumn{3}{|c|}{ Carbonate weight of colony (g) } & \multicolumn{3}{|c|}{ Inorganic matter of weight $(g)$} & \multicolumn{3}{|c|}{ Dry weight of colony (g) } \\
\hline & BS0.8 & BS1.2 & BS1.6 & $\mathrm{BS} 0.8$ & BS1.2 & BS1.6 & BS0.8 & BS1.2 & BS1.6 \\
\hline \multicolumn{10}{|l|}{ Large } \\
\hline 1 & 501.5 & 3009.2 & $16049.1^{b}$ & 980.5 & 5883.0 & 31376.1 & 1305.2 & 7831.4 & 41767.4 \\
\hline 2 & 266.9 & 1601.2 & 8539.9 & 521.7 & 3130.4 & 16695.5 & 694.5 & 4167.1 & 22224.8 \\
\hline 3 & 315.0 & 1661.4 & 6999.5 & 615.8 & 3247.9 & 13684.1 & 819.7 & 4323.6 & 18216.1 \\
\hline 4 & 303.2 & 1263.2 & 3789.7 & 592.7 & 2469.6 & 7408.8 & 789.0 & 3287.5 & 9862.5 \\
\hline 5 & $204.2^{\mathrm{a}}$ & 1077.1 & 4513.7 & 399.2 & 2105.7 & 8824.4 & 531.4 & 2803.0 & 11746.9 \\
\hline Average & 318.2 & 1722.4 & 7978.4 & 622.0 & 3367.3 & 15597.8 & 828.0 & 4482.5 & 20763.5 \\
\hline \multicolumn{10}{|l|}{ Other-shaped } \\
\hline 6 & 113.6 & 780.4 & $5677.8^{\mathrm{b}}$ & 222.0 & 1525.6 & 11100.1 & 295.5 & 2030.9 & 14776.2 \\
\hline 7 & 50.0 & 357.5 & 2844.1 & 97.7 & 698.9 & 5560.2 & 130.1 & 930.4 & 7401.7 \\
\hline 8 & 89.8 & 473.7 & 1995.8 & 175.6 & 926.1 & 3901.7 & 233.7 & 1232.8 & 5193.9 \\
\hline 9 & 60.2 & 361.2 & 1926.4 & 117.7 & 706.1 & 3766.1 & 156.7 & 940.0 & 5013.4 \\
\hline 10 & 117.0 & 487.4 & 1462.2 & 228.7 & 952.9 & 2858.6 & 304.4 & 1268.4 & 3805.3 \\
\hline 11 & 62.5 & 303.5 & 1124.2 & 122.1 & 593.4 & 2197.8 & 162.5 & 789.9 & 2925.7 \\
\hline 12 & 618.2 & 807.4 & 1099.0 & 1208.5 & 1578.5 & 2148.5 & 1608.8 & 2101.3 & 2860.1 \\
\hline 13 & 43.4 & 228.7 & 963.6 & 84.8 & 447.1 & 1883.9 & 112.8 & 595.2 & 2507.8 \\
\hline 14 & 42.5 & 224.3 & 945.0 & 83.1 & 438.4 & 1847.5 & 110.7 & 583.6 & 2459.3 \\
\hline 15 & 66.8 & 278.2 & 834.5 & 130.5 & 543.8 & 1631.4 & 173.7 & 723.9 & 2171.7 \\
\hline 16 & 50.9 & 212.3 & 636.8 & 99.6 & 415.0 & 1244.9 & 132.6 & 552.4 & 1657.1 \\
\hline 17 & 288.3 & 375.7 & 512.6 & 563.7 & 734.6 & 1002.1 & 750.4 & 977.9 & 1334.0 \\
\hline 18 & $23.6^{\mathrm{a}}$ & 98.2 & 294.5 & 46.1 & 191.9 & 575.8 & 61.3 & 255.5 & 766.5 \\
\hline Average & 125.1 & 383.7 & 1562.8 & 244.6 & 750.2 & 3055.3 & 325.6 & 998.6 & 4067.1 \\
\hline \multicolumn{10}{|l|}{ Single-stalk } \\
\hline 19 & 4.8 & 21.4 & $76.1^{b}$ & 9.3 & 41.9 & 148.9 & 12.4 & 55.7 & 198.2 \\
\hline 20 & 4.8 & 19.4 & 57.4 & 9.4 & 37.9 & 112.2 & 12.4 & 50.4 & 149.4 \\
\hline 21 & 4.5 & 18.3 & 54.3 & 8.9 & 35.9 & 106.3 & 11.8 & 47.7 & 141.4 \\
\hline 22 & 4.4 & 17.7 & 52.6 & 8.6 & 34.7 & 102.8 & 11.4 & 46.2 & 136.9 \\
\hline 23 & 3.7 & 15.6 & 49.2 & 7.2 & 30.4 & 96.1 & 9.6 & 40.5 & 127.9 \\
\hline 24 & 3.5 & 14.7 & 45.1 & 6.9 & 28.6 & 88.3 & 9.2 & 38.1 & 117.5 \\
\hline 25 & 3.2 & 12.8 & 37.8 & 6.2 & 25.0 & 74.0 & 8.2 & 33.2 & 98.5 \\
\hline 26 & $2.0^{\mathrm{a}}$ & 8.2 & 25.1 & 3.8 & 15.9 & 49.1 & 5.1 & 21.2 & 65.4 \\
\hline Average & 3.8 & 16.0 & 49.7 & 7.5 & 31.3 & 97.2 & 10.0 & 41.6 & 129.4 \\
\hline
\end{tabular}

\section{Substrate observation}

\section{Northern slope}

The substrate of the landing point of the ROV Dive \#532 at a water depth of $821 \mathrm{~m}$ on the northern slope of the Shiribeshi Seamount was mainly mud and a few brecciated rocks that appeared to be derived from the jointed volcanic bedrock (Fig. 6). As the ROV ascended the seamount, outcrops of columnar-shaped jointed rocks and very little sediment were observed between 700 and $550 \mathrm{~m}$ depth. Some large breccias from volcanic bedrock buried in the mud were observed up to $530 \mathrm{~m}$. Scarps extended from 530 to $438 \mathrm{~m}$, and large numbers of primnoid coral colonies were observed along the scarps and large breccias. Following this, a flat sandy area continued until ca. $340 \mathrm{~m}$. After this sandy area, a muddy area with a few small breccias was observed up to ca. $300 \mathrm{~m}$. On the slope along the summit at water depths $<300 \mathrm{~m}$, the substrate type gradually changed from sand and gravel to a mixture of sand, gravel, and rubble up to $142 \mathrm{~m}$. Part of the summit was covered with fine mud on top of rubble. Yellow patches were observed on the sea floor at depths of 465 and $253 \mathrm{~m}$.

\section{Eastern slope}

The eastern slope is steeper than the western slope (Fig. 2b). The landing point of Dive \#531 at a depth of $1038 \mathrm{~m}$ was mainly mud with some breccias up to ca. $990 \mathrm{~m}$ (Fig. 6). Volcanic breccias and sediment were observed between 995 and $954 \mathrm{~m}$. The area between 940 and $935 \mathrm{~m}$ had more sediment compared to the other areas of the eastern seamount slope. A columnar- 


\section{(a) all Primnoid coral}

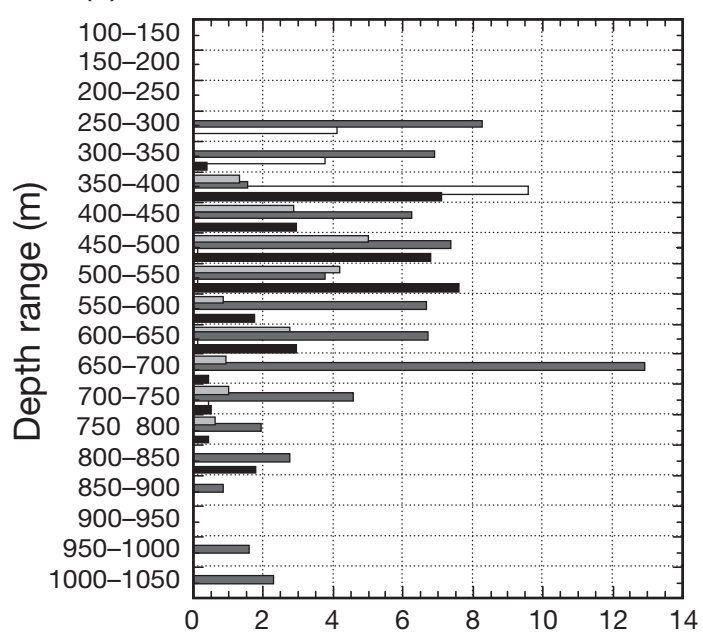

(d) Other shaped morphotype primnoid coral

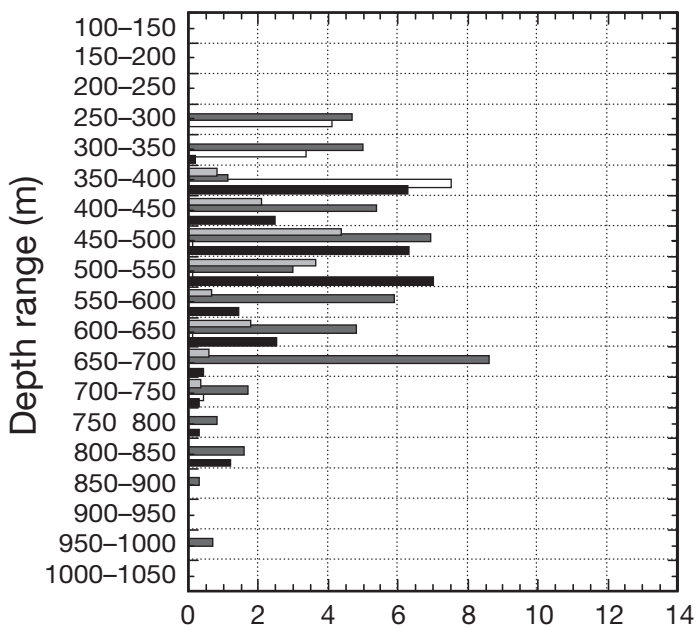

(g) Paragorgiid coral

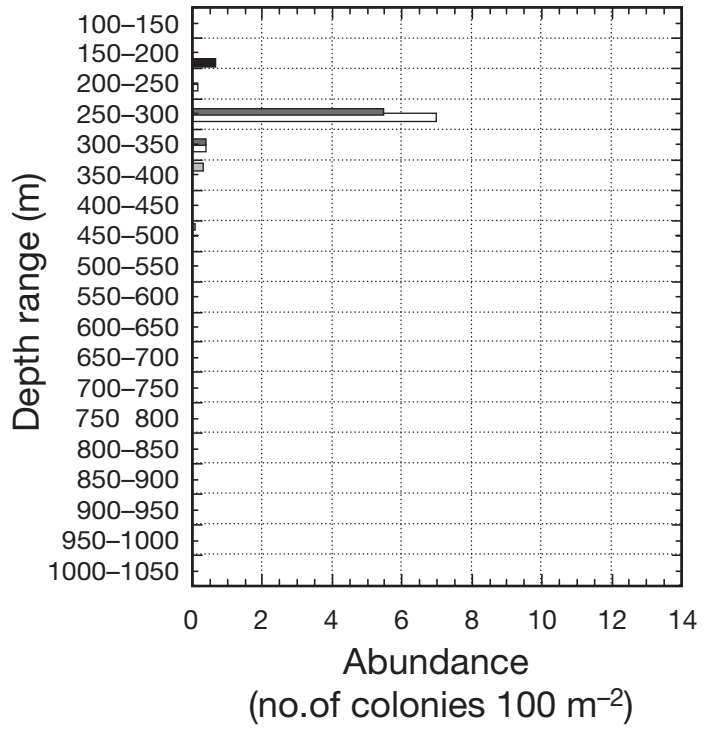

(b) Single morphotype primnoid coral

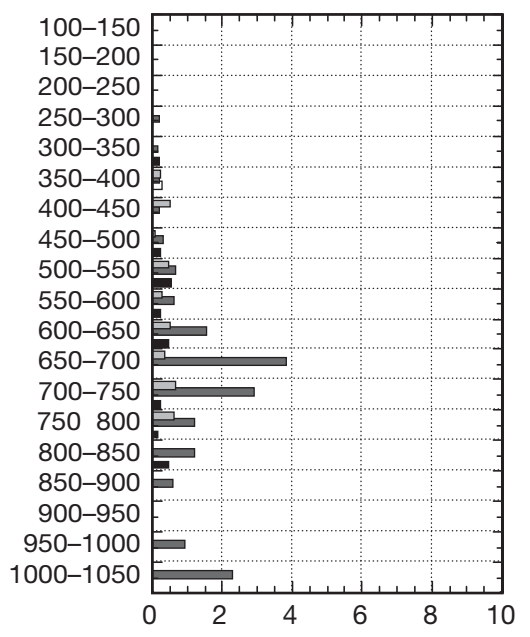

\section{(e) Pink primnoid coral}

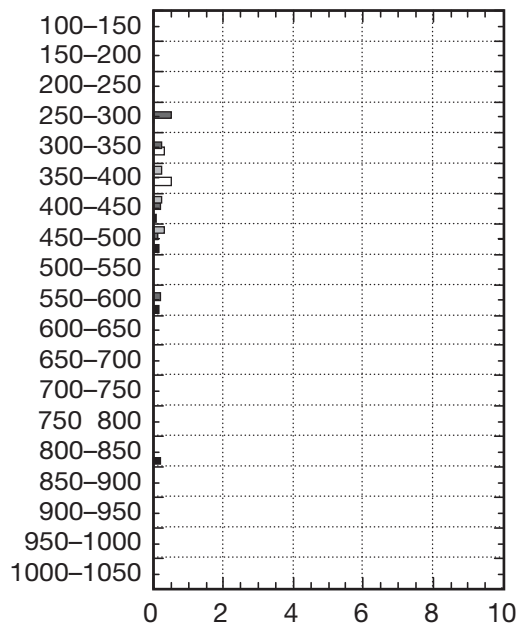

(h) Hydrocoral

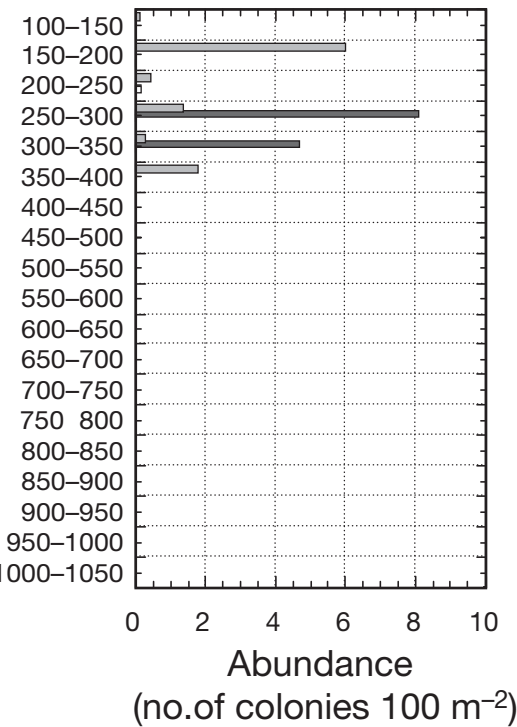

(c) Large morphotype primnoid coral

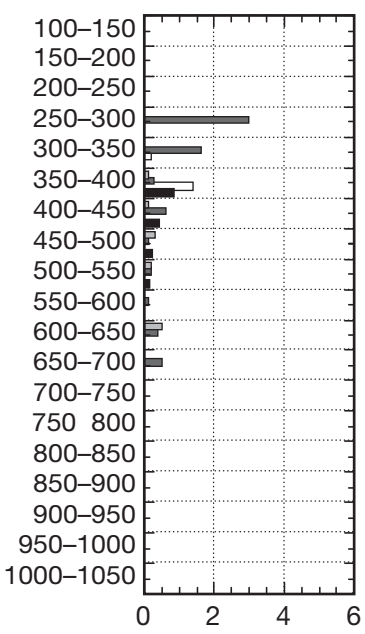

(f) Detached primnoid coral

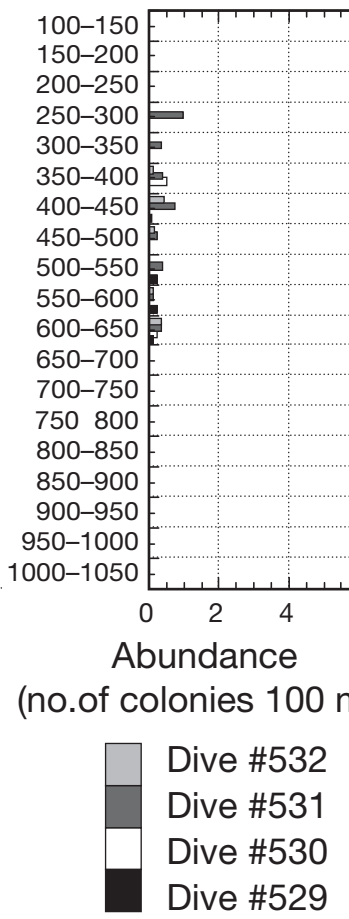

Fig. 5. Average abundance of coral colonies on the Shiribeshi Seamount. Colonies per $100 \mathrm{~m}^{2}$ versus depth of each dive (\#529: southern slope, \#530: western slope, \#531: eastern slope, \#532: northern slope). (a) All primnoid corals. (b) Single-stalk morphotype primnoid corals. (c) Large morphotype primnoid corals. (d) Other-shaped morphotype primnoid corals. (e) Pink primnoid corals. (f) Detached primnoid corals. (g) Paragorgiid corals. (h) Hydrocorals 


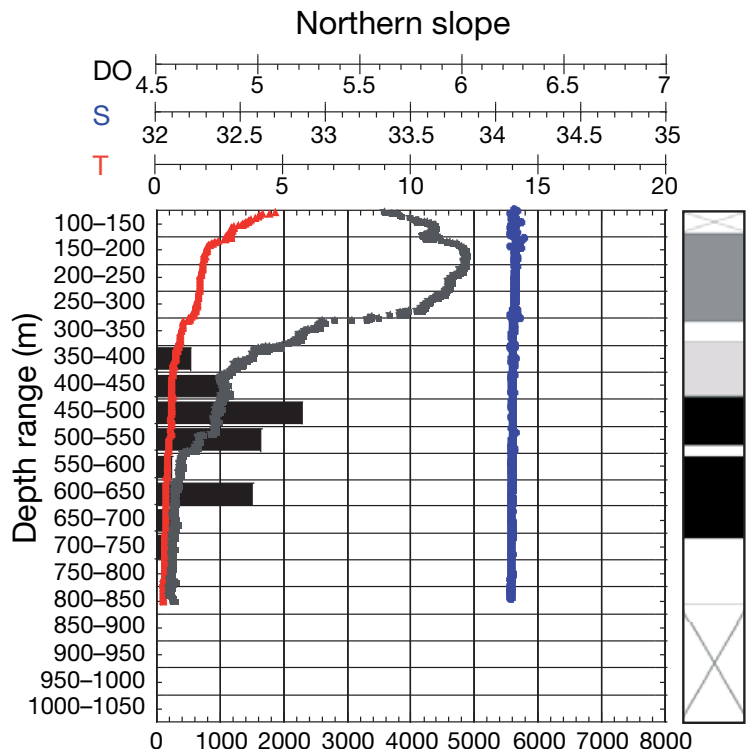

Carbonate standing stock $\left(\mathrm{g} 100 \mathrm{~m}^{-2}\right)$

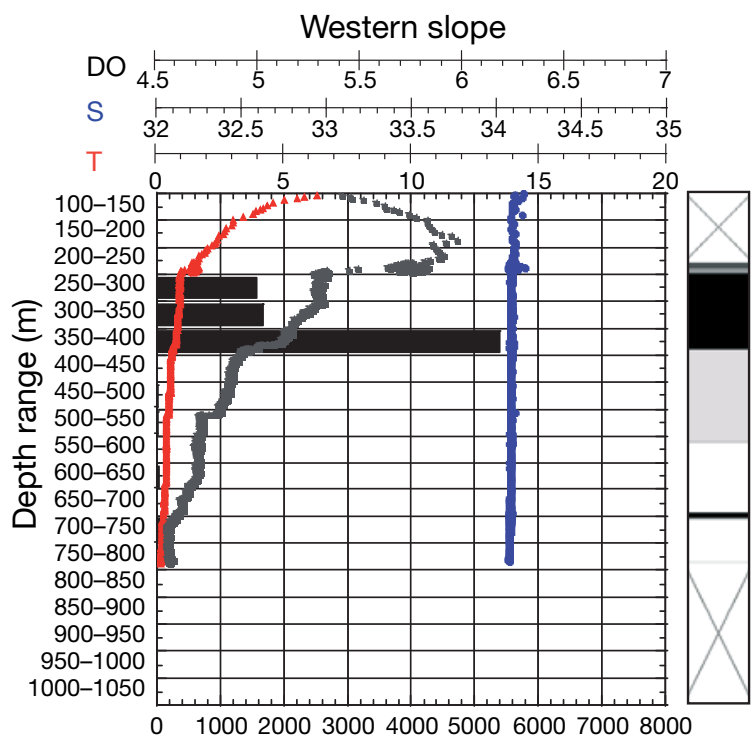

Carbonate standing stock $\left(\mathrm{g} 100 \mathrm{~m}^{-2}\right)$

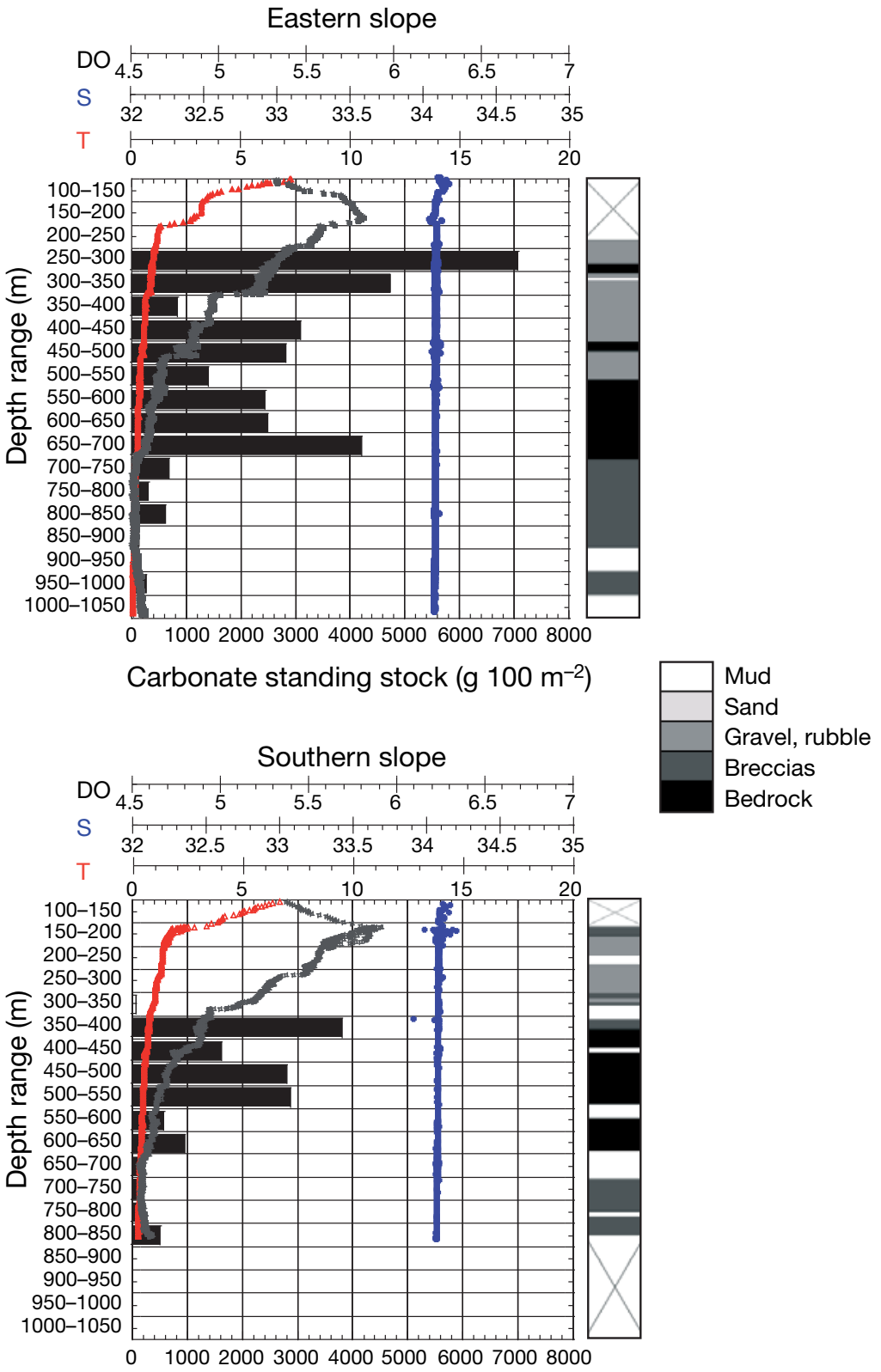

Carbonate standing stock $\left(\mathrm{g} 100 \mathrm{~m}^{-2}\right)$

Fig. 6. Depth distribution of carbonate standing stock $\left(\mathrm{g} 100 \mathrm{~m}^{-2}\right.$, histogram bars) of all primnoid corals in all directions of the Shiribeshi Seamount (northern slope: Dive \#532, eastern slope: Dive \#531, southern slope: Dive \#529, western slope: Dive \#530). Abundance of the carbonate standing stock was calculated with the data from Tables $1 \& 3$ and Fig. 5. Vertical profiles of water temperature ( $\mathrm{T}$ : $\mathrm{red}_{i}{ }^{\circ} \mathrm{C}$ ), salinity (S: blue; PSU) and dissolved oxygen (DO: gray; $\mathrm{ml} \mathrm{l}^{-1}$ ) concentration on each ascent dive are shown on the distribution graph. Right bar of graphs shows substrate observations with $10 \mathrm{~m}$ intervals made by analysing the dive transects. Mud: white; sand: light gray; mixture of gravel and rubble: medium gray; breccias: dark gray; bedrock: black. X in boxes: ROV did not survey at that depth

shaped jointed rock area began at a depth of $889 \mathrm{~m}$ and continued upward. Outcrops of volcanic bedrock and large breccias were present between the depths of 700 to $531 \mathrm{~m}$, and there were some detached primnoid corals at $543 \mathrm{~m}$ with collapsed outcrops. A mixture of mud, breccias, and rubble was observed, which seemed to be caused by collapsed outcrop, at the depths of 531 to 472 and 450 to $324 \mathrm{~m}$. Between the collapse mixtures, the scarp of outcrops and large breccias extended from a depth of 472 to $450 \mathrm{~m}$. The substrate type was mud between 324 and $310 \mathrm{~m}$ and then became a mixture of breccias and rubble between 310 and $300 \mathrm{~m}$. Between 300 and $280 \mathrm{~m}$, outcrops of columnar-shaped jointed rock and breccias with corals 
were observed. The slope to the summit at water depths $<280 \mathrm{~m}$ gradually became a mixture of breccias, sand, and rubble. A large number of empty ray egg sacks (sacks after hatching) were observed.

\section{Southern slope}

The ROV arrived on the bottom at a depth of $821 \mathrm{~m}$ (Dive \#529), and there were a large number of breccias up to a depth of $780 \mathrm{~m}$ (Fig. 6). Between 775 and $767 \mathrm{~m}$, the substrate was mainly mud, then a few breccias were found distributed on the mud until a depth of 700 $\mathrm{m}$. Mud was the main substrate from 696 to $627 \mathrm{~m}$. Between 627 and $569 \mathrm{~m}$, scarps and columnar-shaped jointed bedrock were observed, and then the substrate changed to mud with some rubble from 570 to $540 \mathrm{~m}$ deep. Scarps and outcrops of columnar-shaped jointed volcanic bedrock continued from 540 to $429 \mathrm{~m}$, and primnoid corals were observed on these rocks. Between the depths of 429 and $421 \mathrm{~m}$, the substrate was composed of mud with breccias. There were scarps of volcanic breccias between 421 and $384 \mathrm{~m}$. At a depth of $380 \mathrm{~m}$ breccias formed the main substrate, and then the seafloor became mud with a few breccias up to $320 \mathrm{~m}$. A mixture of sand, gravel, and rubble was observed between 316 and $239 \mathrm{~m}$, and some breccias were observed around a depth of $304 \mathrm{~m}$. Along the summit, the substrate type gradually turned to mud and to a mixture of mud, sand, gravel, and rubble. The shallowest point of this dive was a depth of $164 \mathrm{~m}$, and the substrate consisted mainly of breccias.

\section{Western slope}

The western slope is not as steep as the other slopes of the Shiribeshi Seamount (Fig. 2b). Over half the substrates in the dive transect (Dive \#530) were mud or sand (Fig. 6). From $779 \mathrm{~m}$ (the landing point) to $564 \mathrm{~m}$ it consisted of a muddy area. In the muddy area some breccias, interrupted by a volcanic bedrock area between 700 and $688 \mathrm{~m}$, were observed. Then, sand with a small area of gravel was observed between 564 and $430 \mathrm{~m}$. Bedrock was observed between 391 and $252 \mathrm{~m}$. In the bedrock area, scarps were present at depths of 384 to 380,344 , and 317 to $252 \mathrm{~m}$. From 252 to $241 \mathrm{~m}$, the substrate of the slope was a mixture of sand, gravel, and rubble. An area dominated by breccias continued from a depth of 241 to $238 \mathrm{~m} ; 238 \mathrm{~m}$ was the liftoff point of the ROV.

CWOC and hydrocorals are sessile organisms which can only attach to hard substrates. On the Shiribeshi Seamount, they live on breccias or outcrops. They were also observed on several sizes of breccias and rubble in the mud or sand area.

\section{Distribution of CWOC}

The maximum and the highest average abundance of single-stalk morphotype corals was in Dive \#531 on the eastern side of the Shiribeshi Seamount at depths between 650 and $750 \mathrm{~m}$. Water temperature was between 0.45 and $0.33^{\circ} \mathrm{C}$, salinity was $34.08 \mathrm{PSU}$, and DO was between 4.6 and $4.5 \mathrm{ml} \mathrm{l}^{-1}$ (Figs. $5 \& 6$ ). On the eastern side of the seamount, both the deepest and shallowest primnoid colonies were observed. The colony size for 8 colonies of single morphotype corals was estimated using the BS diameter. Their height (= length of colony), using the BS1.2 from the video images for measurement calculations, ranged from 42.16 to $110.71 \mathrm{~cm}$, and their average \pm SD height using BS1.2 for measurement was $82.7 \pm 21.7 \mathrm{~cm}$ (Table 3). A total of 169 single morphotype colonies were distributed between depths of 1030 and $292 \mathrm{~m}$ (water temperature: 0.24 to $1.08^{\circ} \mathrm{C}$, salinity: 34.07 to 34.08 PSU, DO: 4.6 to $5.3 \mathrm{ml} \mathrm{l}^{-1}$ ).

Large morphotype colonies with more than 100 branches were found especially on the eastern side of the seamount (Dive \#531) between a depth range of 250 to $350 \mathrm{~m}$ (water temperature: 1.20 to $0.82^{\circ} \mathrm{C}$, salinity: 34.08 PSU, DO: 5.4 to $5.0 \mathrm{ml} \mathrm{l}^{-1}$ ) (Figs. 5 \& 6). The deepest and shallowest observations (671 and $284 \mathrm{~m}$, respectively) of this morphotype occurred in this same dive. The sizes of 5 colonies of white large morphotype Primnoidae were estimated, and their height range (using BS1.2) was 97.97 to $166.27 \mathrm{~cm}$ while their average \pm SD height was $126.3 \pm 27.8 \mathrm{~cm}$. The average \pm SD volume of the colonies (using BS1.2) was $10064.5 \pm$ $4432.4 \mathrm{~cm}^{3}$ (Table 3). A total of 108 large morphotype colonies were distributed between depths of 671 and $284 \mathrm{~m}$ (water temperature: 0.44 to $1.11^{\circ} \mathrm{C}$, salinity: 34.07 to $34.08 \mathrm{PSU}$, DO: 4.6 to $5.3 \mathrm{ml} \mathrm{l}^{-1}$ ).

On the southern (Dive \#529) and eastern (Dive \#531) sides of the Shiribeshi Seamount, the abundance of other-shaped morphotype primnoid colonies exhibited 2 peaks around depths of 450 to $500 \mathrm{~m}$ (water temperature: 0.71 to $0.50^{\circ} \mathrm{C}$, salinity: 34.07 to $34.08 \mathrm{PSU}$, DO: 4.7 to $4.9 \mathrm{ml} \mathrm{l}^{-1}$ ) and 650 to $700 \mathrm{~m}$ (water temperature: 0.45 to $0.33^{\circ} \mathrm{C}$, salinity: 34.07 to $34.08 \mathrm{PSU}, \mathrm{DO}: 4.6 \mathrm{ml}$ $\mathrm{l}^{-1}$ ) (Figs. $5 \& 6$ ). On the western side (Dive \#530) and the northern side (Dive \#532), peak abundance was observed between 350 and $400 \mathrm{~m}$ (water temperature: 0.98 to $0.75^{\circ} \mathrm{C}$, salinity: 34.09 to $34.07 \mathrm{PSU}$, DO: 5.2 to $4.9 \mathrm{ml} \mathrm{l}^{-1}$ ) and between 450 and $500 \mathrm{~m}$ (water temperature: 0.71 to $0.64^{\circ} \mathrm{C}$, salinity: 34.08 to $34.07 \mathrm{PSU}$, DO: 4.9 to $4.8 \mathrm{ml} \mathrm{l}^{-1}$, respectively). The deepest colony of white other-shaped morphotype primnoid coral was observed at a depth of $968 \mathrm{~m}$ (water temperature: $0.24^{\circ} \mathrm{C}$, salinity: $34.07 \mathrm{PSU}$, DO: $4.6 \mathrm{ml} \mathrm{l}^{-1}$ ) in Dive \#531, and the shallowest colony was observed at $271 \mathrm{~m}$ (water temperature: $1.09^{\circ} \mathrm{C}$, salinity: $34.08 \mathrm{PSU}$, 
DO: $5.3 \mathrm{ml} \mathrm{l}^{-1}$ ) in Dive \#530. The sizes of 13 othershaped morphotype colonies were estimated. The range of estimated height (using BS1.2) was 63.40 to $116.14 \mathrm{~cm}$ (average \pm SD height: $90.5 \pm 16.2 \mathrm{~cm}$ ) and the average \pm SD volume of the colonies (using BS1.2) was $5829.7 \pm 1233.7 \mathrm{~cm}^{3}$ (Table 3). A total of 1157 other-shaped morphotype colonies were distributed between depths of 968 and $271 \mathrm{~m}$ (water temperature: 0.24 to $1.38^{\circ} \mathrm{C}$, salinity: 34.09 to $34.07 \mathrm{PSU}, \mathrm{DO}: 4.6$ to $5.3 \mathrm{ml} \mathrm{l}^{-1}$ ).

The abundance of colonies of pink-coloured primnoid coral was usually very low. It may be a colour variation of Primnoa species. Therefore, in the following estimations of volume and carbonate levels, pink corals are calculated from the data of large or othershaped morphotype colonies. The deepest observation of a pink-coloured colony was recorded at a depth of $822 \mathrm{~m}$ in Dive \#529, and the shallowest colony was observed at $285 \mathrm{~m}$ in Dive \#531. The distribution of a total of 29 pink other-shaped morpho-type colonies was observed between 822 and $285 \mathrm{~m}$ (water temperature: 0.30 to $1.09^{\circ} \mathrm{C}$, salinity: 34.06 to $34.08 \mathrm{PSU}$, DO: 4.6 to $5.3 \mathrm{ml} \mathrm{l}^{-1}$ ).

The detached primnoid corals in the video footage were also counted, and estimations of their volume and carbonate were calculated from the data for large or other-shaped morphotype colonies. A total of 61 detached colonies were distributed between depths of 639 and $284 \mathrm{~m}$ (water temperature: 0.44 to $\left.1.11^{\circ} \mathrm{C}\right)$.

Other corals that also produce carbonate, such as paragorgiid corals and hydrocorals, were observed. Paragorgiid corals were observed most commonly in the eastern (Dive \#531) and western (Dive \#530) areas of the seamount between the depths of 250 and $300 \mathrm{~m}$ (water temperature: 1.21 to $1.06^{\circ} \mathrm{C}$, salinity: 34.09 to 34.08 PSU, DO: 5.4 to $5.3 \mathrm{ml} \mathrm{l}^{-1}$ ). The 105 paragorgiid coral colonies observed were distributed between depths of $491 \mathrm{~m}$ (Dive \#532) and $175 \mathrm{~m}$ (Dive \#529) (water temperature: 0.66 to $1.74^{\circ} \mathrm{C}$, salinity: 34.07 to 34.11 PSU, DO: 4.8 to $5.8 \mathrm{ml}^{-1}$ ).

Though there were a number of hydrocorals, the distribution area was restricted to the eastern and northern parts of the seamount (Dives \#531 and \#532). It is not clear whether these communities contain a single species or several species. The 278 hydrocoral colonies observed were distributed between depths of 361 and $143 \mathrm{~m}$ (water temperature: 0.83 to $2.92^{\circ} \mathrm{C}$, salinity: 34.07 to $34.08 \mathrm{PSU}, \mathrm{DO}: 5.0$ to $5.9 \mathrm{ml} \mathrm{l}^{-1}$ ).

Paragorgiid corals and hydrocorals are all carbonate producers in cold, deep waters; however, in the present paper I only estimated the carbonate production of primnoid corals because the other corals are relatively small, and it is difficult to estimate the size from the video archives. Isididae (bamboo coral) is known to be one of the carbonate-rich octocorals. However, currently there is no record of the family Isididae from this seamount and no specimens have been collected there. I was also not able to distinguish Isididae from other corals in this study.

The average CSS of 'living' CWOC sclerites along all dive transects of the Shiribeshi Seamount estimated from the volume of all morphotype primnoid colonies using BS1.2 (Table 6: calculated from the data in Tables 1 \& 3) was $28.58 \mathrm{~g} \mathrm{~m}^{-2}$ (Table 7). The estimated maximum CSS in all dive transects of the Shiribeshi Seamount was recorded at Dive transect \#531 and was $70.64 \mathrm{~g} \mathrm{~m}^{-2}$ at depths ranging between 250 and $300 \mathrm{~m}$ (Table 7, Fig. 6). The carbonate production values \pm SD were $0.47 \pm 0.01 \mathrm{~g} \mathrm{~m}^{-2} \mathrm{yr}^{-1}$ for the average CSS along all transects and $3.61 \pm 0.06 \mathrm{~g} \mathrm{~m}^{-2} \mathrm{yr}^{-1}$ for the maximum CSS in all dives (in Dive \#531).

\section{DISCUSSION}

\section{Colony content}

As shown in Fig. 4, for the corals observed in this study axis weight percentage increased with growth, while sclerites weight percentage was almost constant after an age of approximately 9 yr. Data in Table 5 suggest that the weight percentage of sclerites within a colony tends to be constant for any given species, generally falling within a specific range. This may be partly due to the distribution of large polyps within a colony that is a main source of large sclerites. It was observed that polyps around the axis become smaller toward the base, though the surface area of the axis increases at the same time. Velimirov \& Böhm (1976) maintained that the total organic matter of gorgonians remains constant throughout a colony and that the actual number of sclerites and/or their size increases towards the base. Those phenomena were not observed in the present study. However, it has been reported for Eunicella spp. that sclerites tend to be larger in the branch regions than at the base, especially if colonies have been exposed to strong water movement (Velimirov 1976, Velimirov \& Böhm 1976). Although water movement was not measured in the collection areas, there may be strong water currents in deep-water coral environments.

As shown in Table 5, this is the first time that the sclerites content from CWOC in the NW Pacific have been determined. Genus Primnoa have a large number of sclerites (= amount of carbonate), i.e. as much as the volume reported in tropical water gorgonians and alcyonaceans. It has been confirmed that CWOC also contain large amounts of carbonate, although the growth rate of CWOC is very low in cold waters. 


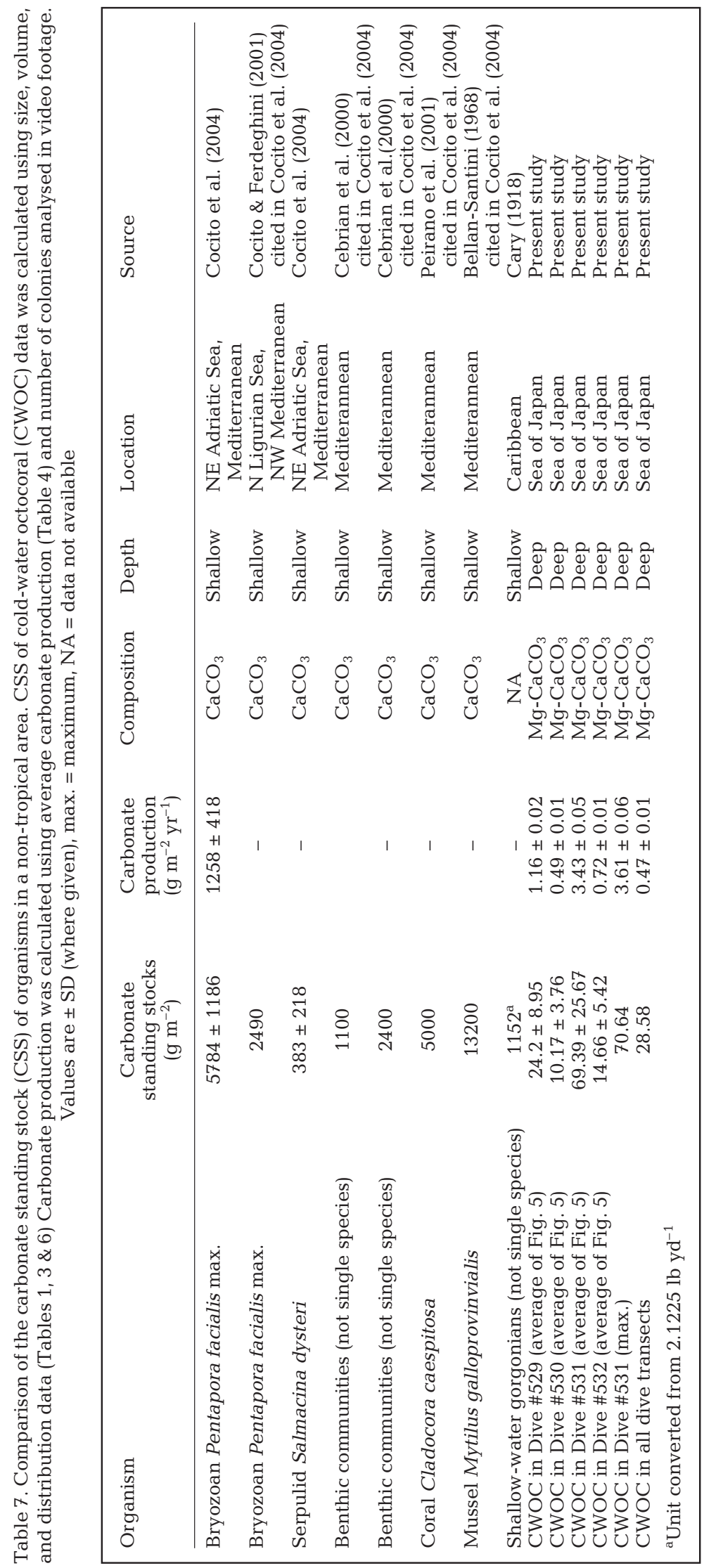

The growth of CWOC is low compared with the growth of warm, tropical and shallow shallow-water gorgonians. Linear growth rates for deep-water gorgonians are $0.3 \mathrm{~cm} \mathrm{yr}^{-1}$ (Corallium japonicum: Grigg 1974b), 1.60 to $2.32 \mathrm{~cm}$ $\mathrm{yr}^{-1}$ (Primnoa Pacifica, Pacific: Andrews et al. 2002 ), 0.15 to $0.25 \mathrm{~cm} \mathrm{yr}^{-1}$ ( $P$. resedaeformis, Atlantic: Risk et al. 2002), $1.7 \mathrm{~cm} \mathrm{yr}^{-1}, 2.2$ to $4.0 \mathrm{~cm} \mathrm{yr}^{-1}(P$. resedaeformis, Paragorgia arborea, respectively: Mortensen \& Buhl-Mortensen 2005), and 0.8 to $1.3 \mathrm{~cm} \mathrm{yr}^{-1}$ (Paragorgia arborea: D. Gordon, NIWA, pers. comm. cited in Mortensen \& Buhl-Mortensen 2005). In contrast, shallow-water gorgonians have linear growth rates of $2.48 \mathrm{~cm} \mathrm{yr}^{-1}$ (Melithaea flabellifera: Matsumoto 1997, 2004), $2.02 \mathrm{~cm} \mathrm{yr}^{-1}$ (Briareum: Brazeau \& Lasker 1992), $4.5 \mathrm{~cm} \mathrm{yr}^{-1}$ (Leptogorgia: Mitchell et al. 1993), $1.69 \mathrm{~cm} \mathrm{yr}^{-1}$ (Muricea: Grigg 1974a), (Paramuricea clavata: Mistri 1995), $2.7 \mathrm{~cm} \mathrm{yr}^{-1}$ (Paramuricea: Mistri \& Checcherelli 1994), and 2.0 to $20.0 \mathrm{~cm} \mathrm{yr}^{-1}$ (Plexaura: Kim \& Lasker 1997). The axial growth rate is also important for such long-lived organisms. Those for CWOC are $0.35 \pm 0.15 \mathrm{~mm} \mathrm{yr}^{-1}$ (Corallium rubrum: Marschal et al. 2004), $0.36 \pm$ $0.05 \mathrm{~mm} \mathrm{yr}^{-1}$ (Primnoa pacifica: Andrews et al. 2002), $0.090 \mathrm{~mm} \mathrm{yr}^{-1}$ (P. resedaeformis: Risk et al. 2002) and $0.24 \mathrm{~mm} \mathrm{yr}^{-1}$ (P. pacifica: Matsumoto 2006, 2007). The slow growth rates suggest their long lifespan, and many studies have actually confirmed a lifespan of several hundred years by means of growth ring counts or isotope dating (Andrews et al. 2002, Risk et al. 2002, Mortensen \& Buhl-Mortensen 2005). This evidence suggests 'living' CWOC could sustain their skeletons and carbonates throughout their long lives. Although their growth rate (= carbonate production speed) is relatively slow compared with those of tropical water corals, they can continue to accumulate and maintain their skeletons and carbonates for hundreds of years.

\section{In situ scales on the video footage}

The largest problem associated with the measurement of CWOC in the video images is that there are no scales in the frames of the submersible camera. In a shallow-water study, it is possible to get accurate micro-scale data using a scale bar or plate in situ. But in deep water and large colonies, it is very difficult to define the scale, especially from video footage from a moving submersible due to parallax of 
the ROV camera and zooming, which was used for the recordings. I have designed a new method which uses the branch diameter of actual specimens of the same species collected from the same locality as that of the dive video and which redefines the scale in the video frame as the BS for coral branch diameter in the video footage. From the video data there were no strong linear correlations between colony height $(\mathrm{cm})$ and the base diameter $(\mathrm{mm})$ for Primnoa pacifica $\left(\mathrm{r}^{2}=\right.$ 0.17993, $\mathrm{p}=0.0308$ ) (Table 3). However, from the examined specimens of $P$. pacifica, the growth rings, which are assumed to represent annual periodicity and hence age, were visible on cross-sections taken along the colony, from base to tip, and from these counts there was a clear correlation with section diameter (Matsumoto 2007). Branch cross-section diameters vary somewhat throughout the colony, ranging from 0.8 to $1.6 \mathrm{~cm}$ (Table 2), and for this reason the mid-value of $1.2 \mathrm{~cm}$ was used for the correlation estimates. The BS estimation method is only possible when both video footage and a specimen of the species are collected from the same locality. In addition, the coral specimen (or some other target in the video) needs to be of a suitable size. Branch diameters also need to be reasonably similar throughout the colony. For these reasons, it was difficult to estimate the size and calculate the volume of both the paragorgiid corals and hydrocorals on this seamount. The large CWOC, genus Primnoa, however, met all requirements for the BS estimation.

The primnoid corals in this study were 42.16 to $166.27 \mathrm{~cm}$ in height with BS1.2. In the northeast Pacific, Primnoa pacifica forms massive stands 2 to $3 \mathrm{~m}$ tall (Krieger \& Wing 2002 cited in Andrews et al. 2002) and the specimen collected was $197.5 \mathrm{~cm}$ in height (Andrews et al. 2002). On the other hand, in the Atlantic Ocean, the height of the colony was estimated to be about 0.5 to $0.75 \mathrm{~cm}$ (Risk et al. 2002) and the maximum size of $P$. resedaeformis reported was $1 \mathrm{~m}$ (Broch 1912, Madsen 1944, Mortensen \& BuhlMortensen 2005). A comparison of these estimated or observed heights seems to show that $P$. pacifica specimens in the Pacific Ocean are larger than $P$. resedaeformis specimens from the Atlantic Ocean. The maximum water temperature in which Primnoa resedae formis was found in the Atlantic Ocean off Canada was $12.1^{\circ} \mathrm{C}$, and the highest abundance of Primnoa colonies was found at average water temperatures between 5.3 and $6.5^{\circ} \mathrm{C}$. (Mortensen \& Buhl-Mortensen 2004). Another distribution record reported temperatures between 5 and $8^{\circ} \mathrm{C}$ (Madsen 1944) in the North Atlantic Ocean. The observation of $P$. pacifica at temperatures between 0.24 and $1.12^{\circ} \mathrm{C}$ in the present study is the coldest temperature distribution on record for this genus.

\section{Coral zonation}

The most significant factor for the distribution of all marine invertebrates is water temperature. An additional critical factor specifically for sessile organisms is substrate type. Larvae settlement of marine sessile organisms depends on the substrate. For sessile organisms such as gorgonian corals or hydrocorals, the critical bottom substrate is hard rock. In the present study, this tendency is apparent in Fig. 6; coral distributions seem to be overlapped with substrate distribution such as breccias or bedrock. At the same time, it is clear that there are differences in the vertical distribution of the primnoid corals, paragorgiid corals and hydrocorals on the Shiribeshi Seamount (Fig. 5). Their vertical zonation is thought to be influenced by water temperature because the reproduction of octocorals is affected by water temperature (Vighi 1970, Grigg 1977, Weinberg \& Weinberg 1979, Matsumoto 1997, 2004), though they have strong tolerance of a wide range of water temperatures. A difference in water temperature of ca. $1{ }^{\circ} \mathrm{C}$ can be a trigger to accelerate gonad development in the early stages of reproduction, and it can cause a difference of $2 \mathrm{wk}$ to $1 \mathrm{mo}$ in the date when planulae shedding occurs (Matsumoto 1997, 2004). Salinity was stable in all dives in the present and previous study (Miyake et al. 2004). It also seems that salinity is not a component which affects the distribution of corals on this seamount. DO data changed among all dives, but it did not seem to be critical for coral distribution on this seamount (Fig. 6). The other factor which affects octocorals habitat is local water current. Because gorgonians are suspension feeders, they commonly inhabit areas characterized by strong, fast-flowing currents and sometimes by upwelling (Reed 1983, Sebens 1984). Unfortunately, current velocity or direction data was not recorded in these dive surveys. However, there was a report that there was a steep change in the direction of the current at $>600$ to $500 \mathrm{~m}$ on the northern slope of the seamount, though the current velocity was low, ca. 0.1 knots $\left(5 \mathrm{~cm} \mathrm{~s}^{-1}\right.$ ) (Ogawa et al. 2002). The different coral distribution between the slopes (Fig. 6) might be affected by exposure to the warm water current (Tsushima Current) from the south, though it is currently not at all clear what effect this current may have on the seamount. Pelagic and bentho-pelagic animals such as jellyfish were also observed during the dives. The distribution of midwater animals were mostly observed in an area deeper than $350 \mathrm{~m}$, where water temperature, salinity and DO were all constant as Miyake et al. (2004) reported. It is suggested that octocorals play a significant role in benthic-pelagic coupling and that they may interact between the pelagic and benthic ecosystems (Raffaelli et al. 2003, Miyake et al. 2004, Matsumoto et al. 2007). 
Observation made in the present study also seemed to support the overlapping of these 2 ecosystems and high biodiversity in the CWOC area on the seamount. Occasionally, fresh but fallen gorgonians were observed. The detachment of these CWOC may not have been caused by trawl gear. In this area of the Okushiri ridge, Sea of Japan, the detached CWOC is said to be useful as an indicator of slope collapse caused by earthquakes (Naganuma 1995). It has been reported that benthic animals can be affected by such underwater earthquakes.

\section{Biogeographical considerations}

The results of the present study describe the coral elements of fauna of temperate and sub-arctic regions. The specimen type Primnoa pacifica (Kinoshita, 1907) was collected in Sagami Bay, near Tokyo on the Pacific side of Japan. No other $P$. pacifica specimen has been collected between the type locality, which is located on the Pacific side of Japan and the Shiribeshi Seamount, which is located in the Sea of Japan. This species seems to be a Pacific specific and has been observed both on the west and east side of the North Pacific Ocean, but it has never been recorded in the Atlantic. In the Sea of Japan, the warm Tsuhima Current flows from a tropical area to the area of the Shiribeshi Seamount, then northwards to the Sea of Okhotsk. In contrast, on the Pacific side of Japan, the cold Oyashio Chishima (Kurile) Current flows north to south. It is difficult to propose a hypothesis that the genus Primnoa originated in the south and moved to the north by means of the currents which we can observe at present (Holocene). There is evidence that the species diversity within this genus of the Pacific Ocean (at least 3 nominal species and 1 variation) is higher than that of the Atlantic Ocean (1 species; P. resedaeformis). It has also been observed that Primnoa species in the Pacific have a high morphological plasticity compared to that of typical P. resedaeformis in the North Atlantic. These differences in species diversity and plasticity may suggest a trans-arctic distribution from the Pacific to the Atlantic or perhaps the reverse.

\section{Non-tropical CSS}

A revision of the terminology concerning 'hermatypic' was proposed by Schuhmacher \& Zibrowius (1985). Because the existence of CWC constructions was already known (Dons 1944, Teichert 1958), the conceptual shortcomings of the previous ecological categorization were evident. Though the term 'ahermatypic corals' includes both deep- and shallow-water corals that do not build reefs, the term 'hermatypic corals' only includes shallow-water corals with symbiotic zooxanthellae. Therefore, CWC were categorized as ahermatypic corals in accordance with the older terminology, even though they build bioherms or biostromes. Schuhmacher \& Zibrowius (1985) proposed using the term 'constructional' for the organisms which form a bioherm that elevates a durable carbonate structure in shallow or deep water, and constructional forms are not necessarily hermatypic. The term 'constructional' could include other bioherm or biostrome constructor organisms such as sponges (Conway et al. 1991, Barrie \& Conway 1999), coralline algae (Bourrouilh-Le \& Hottinger 1988, Carannante et al. 1988), and of course the CWC Lophelia pertusa and its complexes (Mortensen et al. 1995, Freiwald et al. 2002). The results of the present study suggest that CWOC are azooxanthellate and ahermatypic but they also have the capabilities of constructional organisms such as shallow-water octocorals, which can make carbonate limestone with a maximum thickness of $22 \mathrm{~cm}$ (Konishi 1981).

Carbonate sediments of a non-coral reef-type, or 'constructional' type, are volumetrically very important and dominate carbonate platforms in the temperate zone (Carannante et al. 1988). For example, it was believed that sponges do not contribute to reef construction in large quantities at the marine bottom (Milliman 1974). However, this has recently been shown to be incorrect, because large Holocene sponge bioherms that are many kilometres in size were found in cold water off the Canadian coast (Conway et al. 1991). Thus, sponges are clearly a large constructional organism in the cool waters off the Canadian coast. This situation could also be true for CWC. The contribution of CWC to the marine carbonate sediment was previously not known, but after Nelson (1988) suggested the importance of non-tropical carbonate sedimentation (Fig. 1; symbol X), several studies on CWC, especially those on ahermatypic scleractinian corals, have demonstrated their importance as cold-water bioherms and their contribution to marine carbonate production.

Milliman (1974) indicated that the distribution and composition of deep-sea carbonates depend upon 3 major factors: (1) carbonate productivity, (2) terrigenous sedimentation, and (3) the degree of carbonate saturation within the ambient waters. In consideration of these factors, it is necessary to examine factors such as productivity, sustainability, and location of these corals in order to discuss the potential for carbonate production by CWOC.

Many submarine limestones occur in non-depositional environments and have been dredged from the tops of seamounts, banks, and plateaus where sediment cover is not usually developed. This mode of 
limestone lithification is found in environments where water movement is sufficiently strong to prevent sediment accumulation such as on seamounts, banks, and island slopes (Milliman 1974). This is applicable to the CWOC communities on seamounts. This evidence could increase the possibility that CWOC limestone is present on and around the seamount in the present study, though there are water currents in the octocoral habitat on it.

It is believed that octocoral contribute a significant amount of carbonate to modern sediments (Milliman 1974), and octocorals are one of the major carbonate contributors in modern seas (Cary 1918, 1931, Bayer 1956, Konishi 1981). The work of Bathurst (1975) on deep marine carbonates revealed the tendency for aragonite to dissolve at shallower depths than calcite. It is agreed that the sclerites of all species of octocorals are made of high-magnesium calcite (Chave 1954, Lowenstam 1964, Milliman 1974, Matsumoto 2006, 2007). Moreover, octocorals can inhabit deeper layers than hexacorals, which have an aragonitic skeleton. In the deep sea, aragonitic cements are very rare; however, magnesian calcite and calcite predominate (Milliman 1974). Dissolution of $\mathrm{CaCO}_{3}$ did not occur in the CWOC community in the Milliman (1974) study because the most abundant depth range was between 300 and $600 \mathrm{~m}$, which is shallower than the compensation depth for solid $\mathrm{CaCO}_{3}$, which is between 4000 and $5000 \mathrm{~m}$ (Milliman 1974). In addition, there are reports that colony holdfasts of deep-water octocoral families exist ( Hickson 1938, Bayer 1956, Giammona \& Stanton 1980, Grasshoff \& Zibrowius 1983). These calcified holdfasts had not dissolved in the deep waters, and some materials were fossilised and actually preserved. Therefore, CWOC can survive in deep waters. The skeletal minerals of the axes and holdfasts are slightly more complex compared to the sclerites and mineralogy of the holaxonian families Keroeididae, Acanthogorgiidae, Paramuriceidae, and Plexauridae, and the calcaxonian families Ellisellidae, Chrysogorgiidae, Ifalukellidae, and Primnoidae, which are composed of either Mg-calcite or aragonite (Macintyre et al. 2000). These families include both deep- and shallow-water species. The mineralogy of the axes and holdfasts may affect the vertical distribution of octocorals. In this context, it may be appropriate to mention not only the carbonate (sclerites), but also the inorganic matter (sclerites and holdfast axes) in Table 6 and Fig. 3.

The families which include the common large CWOC (genera Primnoa and Paragorgia) which probably produce a large amount of carbonate are family Primnoidae and family Paragorgiidae in both the North Pacific and Atlantic Ocean. The other family which is capable of producing carbonate is Isididae. It is known from the New Zealand National Institute of Water and
Atmospheric Research (NIWA) survey that several broken deposits of bamboo corals (Isididae, Octocorallia) exist in sub-Antarctic waters (workshop at ISDSC4 NIWA, New Zealand, December 2008). However, there is no large size or forest of Isididae in Japanese waters such as is found in New Zealand or in the Southern Hemisphere.

Many studies have measured the carbonate sedimentation of the seabed (Kessler 1973 cited in Brookfield 1988, Bathurst 1975, Nelson et al. 1982 cited in Brookfield 1988). However, there have been few estimates of the CSS of 'living' organisms. There is scant data available on the CSS of shallow, coastal benthic constructors (Table 7). A comparison of this data with the results of the present study in all dive transects showed smaller amounts of CSS or carbonate production in this study than in other shallow-water bioherms or carbonate productive organisms. However, cruises searching for limestone on the Shiribeshi Seamount have not been conducted. The amount of carbonate in each dive line calculated from Tables 1 \& 3 was 149.3 $\mathrm{kg}$ in Dive \#529, 57.7 kg in Dive \#530, $359.3 \mathrm{~kg}$ in Dive \#531, and $84.0 \mathrm{~kg}$ in Dive \#532. The total amount of carbonate of all dive transects is therefore $0.65 \mathrm{t}$. This volume of carbonate on this seamount seems to be very large when compared with shallow, tropical water octocorals, considering that this is a high latitude site and is in deep, cold water $\left(<1^{\circ} \mathrm{C}\right)$ (Cary 1918, 1931, Konishi 1981). CWOC appear to make an important contribution to calcium carbonate production in cold waters. The total area of the dive transects investigated by the submersible was $22752.8 \mathrm{~m}^{2}$. This is a relatively small amount of carbonate if it is spread uniformly over this wide area; the average would be $28.58 \mathrm{~g} \mathrm{~m}^{-2}$ (Table 7). One of the most important attributes of marine organisms is the patchiness (heterogeneity) of biological components in space and time, both vertically and horizontally (Raffaelli et al. 2003) (see Fig. 5). Benthic organisms display patchiness at a range of scales (Hall et al. 1994). It causes one of the major research problems, i.e. that of estimating the true population volume, and in this case, estimating the carbonate volume. It was observed in this study that CWOC are distributed with high abundance patchiness, therefore suggesting a higher carbonate concentration than the average CSS shown in Table 7. The maximum CSS in all dive transects of the Shiribeshi Seamount was calculated to be $70.64 \mathrm{~g} \mathrm{~m}^{-2}$ (Fig. 6, Dive \#531, 250 to $300 \mathrm{~m}$ ). This is not a large amount of carbonate compared with other temperate CSS (Table 7). The heterogeneity of the distribution of marine benthic organisms has been discussed elsewhere (Raffaelli et al. 2003). The heterogeneity of the CSS will have implications for carbonate production estimates for the entire seamount. It is possible that the 
carbonate distribution is more concentrated when the carbonate has a biological origin in marine benthic animals which have a heterogeneous distribution, as in the case of CWOC. To estimate the CWOC carbonate sediment or limestone around the Shiribeshi Seamount, several complex conditions such as heterogeneity of coral distribution (Fig. 6), bioerosion, current transport, and circulation patterns must be considered (Farrow \& Fyfe 1988).

\section{CONCLUDING REMARKS}

The results of the present study suggest that CWOC fauna has the potential to be the most important element contributing to the formation of carbonate sediments or limestone. The existence of shallow and tropical octocoral-origin limestone or carbonate has already been reported (Fig. 1). Based on the data in Table 6 and Fig. 6 , the amount of sclerites in gorgonian colonies would be at least $0.65 \mathrm{t}$ in total at all dive transects $\left(22752.81 \mathrm{~m}^{2}\right)$ at the Shiribeshi Seamount in this study. It should be mentioned that the research dives were conducted in 4 directions (north, south, west and east-northeast) from the seamount and from $>1000 \mathrm{~m}$ in depth to the top of the seamount (Fig. 2b). This means that if we could conduct research on the sedimentary deposits of the Shiribeshi Seamounts, or some adjacent area, with respect to the heterogeneity of the distribution shown in Fig. 6 and on several conditions such as the local current, we may discover some very interesting carbonate fractions from CWOC.

Octocorals are distributed universally in polar, temperate and tropical regions, but have been identified in lime or sediment only to a limited degree and studies of these corals in lime or sedimentary environments are scant because of the difficulties in observing or sampling in such materials, or simply because of ignorance of (the possibility of) their existence in these environments. In previous paleoecological studies the presence of octocoral traces found in limestone or sediment has been interpreted as meaning that the ancient environment of the deposition was warm and shallow waters; such surveys have been conducted only in tropical environments. The vertical distribution pattern of the peak abundance of primnoid and paragorgiid corals in the present study might be a common phenomenon in this northern area of the Sea of Japan. The temperature records for both Primnoa and Paragorgia in the present study are the coldest observations for these genera. The high abundance of these CWOC in an environment with extremely low water temperatures suggests that the habitat of and contribution to carbonate production by CWOC could include very high latitude and cold-water regions.
Carbonate production may happen wherever octocorals exist, even in Arctic or Antarctic waters. CWOC families which have this potential are the Primnoidae, Paragorgiidae and Isididae in the whole Pacific Ocean area and especially the genera Primnoa and Paragorgia in Japan. The carbonate production of CWOC may be a universal phenomenon. It is worth noting that the method used for estimation in this study is important for further studies on living or sedimented deep-water CSS. The carbonate contribution of CWOC may be large given the longevity and wide range distribution of this group.

Acknowledgements. A.K.M. acknowledges T. Matsui, T. Oji, K. Tanabe, H. Kayane, and T. Fujita. Thanks go to the National Science Museum Tokyo and University of Tokyo and JAMSTEC, which provided specimens, facilities and video archives. Thanks also go to Y. Nakano, who helped with the multibeam map drawing. The manuscript was improved by the comments of 3 anonymous reviewers and by D. Tracey, to whom I am indebted. This study was partly supported by funding to the University of Tokyo from the Nippon-Foundation.

\section{LITERATURE CITED}

Andrews AH, Cordes EE, Mahoney MM, Munk K (2002) Age, growth and radiometric age validation of a deep-sea, habitat-forming gorgonian (Primnoa resedaeformis) from the Gulf of Alaska. Hydrobiologia 471:101-110

Barrie JV, Conway KW (1999) Late Quaternary glaciation and postglacial stratigraphy of the northern Pacific margin of Canada. Quat Res 51:113-123

Bathurst RG (1975) Carbonate sediments and their diagenesis, 2nd edn. Elsvier, New York

Bayer FM (1955) Remarkably preserved fossil sea-pens and their Recent counterparts. J Wash Acad Sci 45(9):294-300

Bayer FM (1956) Octocorallia. In: Moore RC (ed) Treatise on invertebrate paleontology. Part F. Coelenterata. Geological Society of America and University of Kansas Press, Lawrence, KS, p 163-231

Bayer FM (1961) The shallow-water Octocorallia of the West Indian region. A manual for marine biologists. Stud Fauna Curacao Other Caribbean Isl 12:1-373

Bell N, Smith J (1999) Coral growing on North Sea oil rigs. Nature 402:601

Bengtson S (1981) Atractosella, a Silurian alcyonacean octocoral. J Paleontol 55:281294

Bourrouilh-Le JFG, Hottinger LC 1988 Occurrence of rhodolites in the tropical Pacific-a consequence of MidMiocene paleo-oceanographic change. Sediment Geol 60: 355-367

Brazeau DA, Lasker HR (1992) Growth rates and growth strategy in a clonal marine invertebrate, the Caribbean octocoral Briareum asbestinum. Biol Bull 183:269-277

Broch H (1912) Die Alcyonarien des Trondhjemsfjordes II. Gorgonacea. K Nor Vidensk Selsk Skr 1912 (2):1-48

Broch H (1935) Oktokorallen des nördlichsten pazifischen Ozeans und ihre Beziehungen zur atlantischen Fauna. Avh Norske Vidensk-Akad Oslo Math-Natur Kl 1935:1-53

Brook FJ (1998) Stratigraphy and paleontology of Pleistocene submarine volcanic-sedimentary sequences at the northern Kermadec Islands. J R Soc NZ 28:235-257 
Brookfield ME (1988) A Mid-Ordovician temperate carbonate shelf — the Black River and Trenton Limestone Groups of southern Ontario, Canada. Sediment Geol 60:137-153

Carannante G, Esteban M, Milliman JD, Simone L (1988) Carbonate lithofacies as paleolatitude indicators: problems and limitations. Sediment Geol 60:333-346

Cary LR (1918) The Gorgonacea as a factor in the formation of coral reefs. Carnegie Inst Wash Publ 213:341-362

Cary LR (1931) Studies on the coral reefs of Tutuila, America Samoa with special reference to the Alcyonaria. Carnegie Inst Wash Publ 413. Pap Tortugas Lab 27:53-98

- Chave KE (1954) Aspects on the biogeochemistry of magnesium. 1. Calcareous marine organisms. J Geol 62:266-283

Cocito S, Novosel M, Novosel A (2004) Carbonate bioformations around underwater freshwater springs in the northeastern Adriatic Sea. Facies 50(1):13-17

Conway KW, Barrie JV, Austin WC, Luternauer JL (1991) Holocene sponge bioherms on the western Canadian continental shelf. Cont Shelf Res 11:771-790

Dons C (1944) Norges korallrev. K Nor Vidensk Selsk Forh 16:37-82

Ehrlich H, Etnoyer P, Litvinov SD, Olennikova MM and others (2006) Biomaterial structure in deep-sea bamboo coral (Anthozoa: Gorgonacea: Isididae): perspectives for the development of bone implants and templates for tissue engineering. Materialwiss Werkstofftech 37: 552-557

Etnoyer P, Morgan LE (2005) Habitat forming deep-sea corals in the Northeast Pacific Ocean. In: Freiwald A, Roberts JM (eds) Cold-water corals and ecosystems. Springer-Verlag, Heidelberg, p 331-343

Farrow GE, Fyfe JA (1988) Bioerosion and carbonate mud production on high-latitude shelves. Sediment Geol 60: 281-297

Freiwald A (1998) Geobiology of Lophelia pertusa (Scleractinia) reefs in the North Atlantic. Habilitation thesis, Bremen University, Bremen

Freiwald A, Roberts JM (eds) (2005) Cold-water corals and ecosystems. Springer-Verlag, Berlin

Freiwald A, Huhnerbach V, Lindberg B, Wilson JB, Campbell J (2002) The Sula Reef Complex, Norwegian Shelf. Facies 47:179-200

Giammona CP, Stanton RJ Jr (1980) Octocorals from the Middle Eocene Stone City Formation, Texas. Paleontology 54(1):71-80

Goldberg WM (1988) Chemistry, histochemistry and microscopy of the organic matrix of spicules from a gorgonian coral. Histochemistry 89(2):163-170

Grasshoff M, Zibrowius H (1983) Kalkkrusten auf Achsen von Hornkorallen, rezent und fossil (Cnidaria, Anthozoa, Gorgonaria). Senckenb Marit 15:111-145

Grigg RW (1974a) Growth rings: annual periodicity in two gorgonian corals. Ecology 55:876-881

Grigg RW (1974b) Distribution and abundance of precious corals in Hawaii. In: Cameron AM, Cambell BM, Cribb $A B$, Endeau R and others (eds) Proc 2nd Int Coral Reef Symposium. Great Barrier Reef Committee, Brisbane, p 235-240

Grigg RW (1977) Population dynamics of two gorgonian corals. Ecology 58:278-290

Hall SJ, Raffaelli D, Thrush SF (1994) Patchiness and distribution in shallow water benthic assemblages. In: Giller PS, Hildrew AG, Raffaelli DG (eds) Aquatic ecology: scale, pattern and process. Blackwell Scientific Publications, Oxford, p 333-375

Hickson SJ (1938) An alcyonarian from the Eocene of Mississippi. J Wash Acad Sci 28:49-51
Kessler P (1973) The structural and geomorphic evolution of the Persian Gulf. In: Purser BH. (ed) The Persian Gulf. Springer-Verlag, New York, p 11-32

> Kim K, Lasker HR (1997) Flow-mediated resource competition in the suspension feeding gorgonian Plexaura homomalla (Esper). J Exp Mar Biol Ecol 215:49-64

Kocurko MJ (1987) Shallow-water Octocorallia and related submarine lithification, San Andres Island, Colombia. Tex J Sci 39(4):349-365

Kocurko MJ (1988) Note on fossil octocorals and comparisons of some modern and ancient octocoral remains. Tulane Stud Geol Paleontol 21(3/4):105-115

Kocurko MJ, Kocurko DJ (1992) Fossil Octocorallia of the Red Bluff Formation, Lower Oligocene, Mississippi. J Paleontol 66(4):594-602

Konishi K (1981) Alcyonarian spiculite: limestone of soft corals. In: Gomez ED, Birkeland CE, Buddemeier RW, Johannes RE and others (eds) Proc 4th Int Coral Reef Symposium, Manila. Marine Sciences Center, University of the Philippines, Manila, p 643-649

Lasker HR, Boller ML, Castanaro J, Sanchez JA (2003) Determinate growth and modularity in a gorgonian octocoral. Biol Bull 205:319-330

Lindström M (1978) An octocoral from the Lower Ordovician of Sweden. Geologica Palaeontol 12:41-52

Lowenstam HA (1964) Coexisting calcites and aragonites from skeletal carbonates of marine organisms and their strontium and magnesium contents. In: Miyake Y, Koyama T (eds) Resent researches in the fields of hydrosphere, atmosphere and nuclear geochemistry. Maruzen, Tokyo, p 373-404

Macintyre IG, Bayer FM, Logan MAV, Skinner HCW (2000) Possible vestige of early phosphatic biomineralization in gorgonian octocorals (Coelenterata). Geol 28:455-458

Madsen FJ (1944) Octocorallia. Danish Ingolf-Exped 5(13): $1-65$

> Malakoff D (2003) Cool coral hot spot. Science 299:195

- Marschal C, Garrabou J, Harmelin JG (2004) A new method for measuring growth and age in the precious red coral Corallium rubrum (L.). Coral Reefs 23:423-432

Matsumoto A (1997) Growth and reproduction of Melithaea flabellifera. MS thesis, Ochanomizu University, Tokyo (in Japanese)

Matsumoto AK (2004) Heterogeneous and compensatory growth in Melithaea flabellifera (Octocorallia: Melithaeidae) in Japan. Hydrobiologia 530/531:389-397

Matsumoto AK (2005) Recent observations on the distribution of deep-sea coral communities on the Shiribeshi Seamount, Sea of Japan. In: Freiwald A, Roberts JM (eds) Cold-water corals and ecosystems. Springer-Verlag, Berlin, p 345-356

Matsumoto AK (2006) Gorgonian corals as a calcium-carbonate producer in cold waters. $\mathrm{PhD}$ thesis, The University of Tokyo

Matsumoto AK (2007) Effects of low water temperature on growth and magnesium carbonate concentrations in deepwater gorgonians (Primnoa pacifica). Bull Mar Sci 81: 423-435

Matsumoto AK, Iwase F, Imahara Y, Namikawa H (2007) Bathymetric distribution and biodiversity of cold-water octocorals (Coelenterata: Octocorallia) in Sagami Bay and adjacent waters of Japan. Bull Mar Sci 81(Suppl):231-252

Milliman TD (1974) Recent sedimentary carbonates, Part 7. In: Milliman JD (ed) Marine carbonates. Springer-Verlag, Heidelberg, p 1-15

Mistri M (1995) Gross morphometric relationships and growth in the Mediterranean gorgonian Paramuricea clavata. Boll Zool 62:5-8 
Mistri M, Ceccherelli VU (1994) Growth and secondary production of the Mediterranean gorgonian Paramuricea clavata. Mar Ecol Prog Ser 103:291-296

Mitchell ND, Dardeau MR, Schroeder WW (1993) Colony morphology, age structure, and relative growth of two gorgonian corals, Leptogorgia hebes (Verrill) and Leptogorgia virgulata (Lamarck), from the northern Gulf of Mexico. Coral Reefs 12:65-70

Miyake H, Lindsay DJ, Kubota S (2004) Midwater and bentho-pelagic animals on the south slope of Shiribeshi Seamount off the west coast of Hokkaido. JAMSTEC Deep-Sea Res 24:37-42 (in Japanese with English abstract)

Mortensen PB, Buhl-Mortensen L (2004) Distribution of deepwater gorgonian corals in relation to benthic habitat features in the Northeast Channel (Atlantic Canada). Mar Biol 144:1223-1238

Mortensen PB, Buhl-Mortensen L (2005) Morphology and growth of the deep-water gorgonians Primnoa resedaeformis and Paragorgia arborea. Mar Biol 147:775-788

Mortensen PB, Hovland M, Brattegard T, Farestveit R (1995) Deep water bioherms of the scleractinian coral Lophelia pertusa (L.) at $64^{\circ} \mathrm{N}$ on the Norwegian shelf: structure and associated megafauna. Sarsia 80:145-158

Naganuma T (1995) Sediment fatty acids from the Shiribeshi Seamount in the eastern margin of the Japan Sea: a comparison with cold seep sediments. JAMSTEC Deep-Sea Res 11:403-410 (in Japanese with English abstract)

> Nelson CS (1988) An introductory perspective on non-tropical shelf carbonates. Sediment Geol 60:3-12

Nelson CS, Hancock GF, Kamp PJJ (1982) Shelf to basin, temperate skeletal carbonate sediments, Three Kings Plateau, New Zealand. J Sediment Petrol 52:717-732

Ogawa M, Takeuchi A, Hattori M, Okano M and others (2002) Geological and microbial anomalies in the extinct submarine volcano, Shiribeshi Seamount, in the eastern margin of the Japan Sea. Island Arc 11:274-286

Raffaelli D, Bell E, Weithoff G, Matsumoto A and others (2003) The ups and downs of benthic ecology. Considerations of scale, heterogeneity and surveillance for benthic-pelagic coupling. J Exp Mar Biol 285-286:191-203

Editorial responsibility: Karen Miller,

Hobart, Australia
Reed JK (1983) Nearshore and shelf-edge Oculina coral reefs: the effects of upwelling on coral growth and on the associated faunal communities. In: Reaka M L (ed) The ecology of deep and shallow coral reefs. NOAA Undersea Research Program, US Department of Commerce, Washington, DC, p 119-124

> Risk MJ, Heikoop JM, Snow MG, Beukens R (2002) Lifespans and growth patterns of two deep-sea corals: Primnoa resedaeformis and Desmophyllum cristagalli. Hydrobiologia 471:125-131

> Schuhmacher H, Zibrowius H (1985) What is hermatypic? A redefinition of ecological groups in corals and other organisms. Coral Reefs 4:1-9

Sebens KP (1984) Water flow and coral colony size: interhabitat comparisons of the octocoral Alcyonium siderium. Proc Natl Acad Sci USA 81:5473-5477

Takeuchi A, Tanaka T (1990) Geomorphology, geology and tectonics of the Shiribeshi Seamount, northern Sea of Japan. JAMSTEC Deep-Sea Res 6:317-326 (in Japanese with English abstract)

Teichert C (1958) Cold and deep-water coral banks. Bull Am Assoc Petrol Geol 42:1064-1082

- Velimirov B (1976) Variations in growth forms of Eunicella cavolinii Koch (Octocorallia) related to intensity of water movement. J Exp Mar Biol Ecol 21:109-117

Velimirov B, Böhm EL (1976) Calcium and magnesium carbonate concentrations in different growth regions of gorgonians. Mar Biol 35:269-275

Vighi M (1970) Ricerche sul cicio reproductivo del corallo rosso (Corallium rubrum (L.)) del promontorio di Portofino. Atti Accad Lmcei Roma 8:1-26

Weinbauer MG, Velimirov B (1995) Morphological variations in the Mediterranean sea fan Eunicella cavolini (Coelenterata: Gorgonacea) in relation to exposure, colony size and colony region. Bull Mar Sci 56:283-295

Weinberg S, Weinberg F (1979) The life cycle of a gorgonian: Eunicella singularis (Esper, 1794). Bijdr Dierkd 48:127-140

Wilson JB (1988) A model for temporal changes in the faunal composition of shell gravels during a transgression on the continental shelf around the British Isles. Sediment Geol 60:95-105

Submitted: March 2, 2009; Accepted: October 27, 2009

Proofs received from author(s): January 10, 2010 